\title{
THE ASSESSMENT OF HUMAN BIOCLIMATE OF VRANJE HEALTH RESORT (SERBIA) BASED ON UNIVERSAL THERMAL CLIMATE INDEX (UTCI) WITH THE FOCUS ON EXTREME BIOTHERMAL CONDITIONS
}

\author{
Milica Pecelj $j^{1,2,3}$ (D) Anna Błażejczyk ${ }^{4}$ \\ Ivanović ${ }^{6}$ (D) \\ ${ }^{1}$ Geographical Institute "Jovan Cvijić" \\ Serbian Academy of Science and Arts \\ Djure Jaksća street 9, 11000, Belgrade: Serbia \\ ${ }^{2}$ Department of Geography, Faculty of Philosophy \\ University of East Sarajevo \\ Alekse Šantića street 1, 71432, Pale, Republic \\ of Srpska: Bosnia and Herzegovina \\ ${ }^{3}$ Institute of Sports, Tourism and Service \\ South Ural State University \\ Sony Krivoy street 60,454080 , Chelyabinsk: Russia \\ e-mail: milicapecelj@gmail.com
}

\author{
${ }^{4}$ Laboratory of Bioclimatology \\ and Environmental Ergonomics \\ Bioklimatologia \\ Łukowska 17/55, 04-133 Warszawa, Poland \\ e-mail: anna@blazejczyk.eu \\ ${ }^{5}$ Faculty of Geography \\ University of Belgrade \\ Studentski trg 3, 11000, Belgrade: Serbia \\ e-mail: vagic@live.com \\ ${ }^{6}$ School of Electrical Engineering \\ University of Belgrade \\ Bulevar kralja Aleksandra 73, 11120, Belgrade: Serbia \\ e-mail: peca.ivanovic@yahoo.com
}

\begin{abstract}
The study deals with an assessment and interpretation of the bioclimatic conditions in Vranje (southern Serbia). The study aims at temporal distributions of bioclimatic conditions focussing on extreme thermal stress based on the Universal Thermal Climate Index (UTCI). The meteorological data required for the calculation of UTCI concern hourly (7 and 14 CET) weather data collected for the period 2000-2017. The frequency of very strong heat stress (VSHS), very strong cold stress (VSCS) and extreme cold stress (ECS) for both morning and midday hours. Furthermore, the daily difference of the UTCI hourly values (diurnal UTCI change) are specified, giving the daily variance of heat and cold stress. The results revealed the frequency of days in which thermal stress prevails for the studied period. The obtained results show an increase in extreme heat biothermal conditions, while extreme cold biothermal conditions are in decline, especially in the last 10 years. However, the frequency (the number of days) of very strong heat stress (VSHS) increased since 2007. A spectacular increase in heat stress was observed in the month of September, particularly in 2015.
\end{abstract}

\section{Key words}

biothermal conditions $\cdot \mathrm{UTCl} \cdot$ very strong heat stress $\cdot$ very strong cold stress $\cdot$ Vranje 


\section{Introduction}

It is known that weather and climate influence human health and well-being. Based on meteorological data, it is possible to analyse and evaluate weather and climate for tourism, recreation and rehabilitation. Numerous methods are used in human bioclimatology to assess the impact of weather and climate on human health. In the past decade, plenty of research has been published analysing bioclimatic conditions based on heat budget indices. Taking into consideration the wide spatial dimension of diverse geographic regions in which the analyses can be conducted, the UTCl index is more frequently used. Mostly, the index was applied in Europe (Błażejczyk et al., 2010b; Nemeth, 2011; Nastos \& Matzarakis, 2012; Milewski, 2013; Bleta et al., 2014; Błażejczyk \& Błażejczyk, 2014; Matzarakis et al., 2014; Urban \& Kyselý, 2014; Burkart et al., 2016; Makosza \& Nidzgorska-Lencewicz, 2017; Di Napoli et al., 2018, 2019; Kolendowicz et al., 2018; Tomczyk \& Owczarek, 2019). The UTCI was also used in bioclimatic research in Iran (Farajzadeh et al., 2015, Nassiri et al. 2017; Roshan et al., 2018), China (Cheung \& Hart, 2012), Australia (Coutts et al., 2016), Brasil (Bröde et al., 2012), Israel (Potchter et al., 2018), Japan (Honjo et al., 2018), Benin (Vissine et al., 2013), USA (Hartz et al., 2013). In Serbia, some overview information regarding the UTCI Index was presented for several stations but mainly analysing the extreme months of January and July (Pecelj et al., 2017, 2018). In particular, a basic bioclimatic review of heat budget index Heat Load on Man was carried out for Vranje (Pecelj et al., 2013; Milovanović et al., 2017a). Specifically, for Vranje, a basic bioclimatic review was performed based on the equivalent temperature (Stevanović, 2019) and the Heat Load on Man heat budget index (Pecelj et al., 2013; Milovanović et al., 2017a). There are many studies where extreme temperatures determine extreme climate in different ways (Kostopoulou \& Jones, 2005; IPCC, 2007; Radinović \& Ćurić, 2011; Unkašević
\& Tošić, 2011, 2015; Croitorua \& Piticarb, 2013; Milovanović et al., 2018) considering it as one of the most influential climatic parameters in the universal context of climate change. Otherwise, regarding extreme climatic conditions in Serbia, Unkašević \& Tošić (2015) analysed maximum and minimum temperatures to calculate thermal indices (selected from the list of climate change indices recommended by the WMO's Commission for Climatology and the Research Programme on Climate Variability and Predictability (CLIVAR). Following this, the duration and severity of cold and heat waves were estimated even for Vranje. Vranje region is one of the hottest hyperthermal health spa centres in Europe and is already affirmed as a health spa resort in Serbia which emphasises the importance of this region for tourism, recreation and rehabilitation.

Serbia is known for its various mineral, thermal and thermo-mineral springs, which represent the main potential for the development of health spa resorts called "banje". In general, a thermomineral health spa resort in Serbia (banja) can be characterised as a complex of natural subjects such as thermo-mineral springs, noble gases and healing mud (peloid), clean air, climatic elements with pronounced stimulating, calming and preventive effects on strengthening the human body, and diverse vegetation. According to the Official Gazette of the Republic of Serbia about Spas (Law on Spas, Official Gazette of the Republic of Serbia, No.67, August 30, 1993), a spa is a natural good of general interest managed by the state. Spa resorts are areas where one or more natural healing factors exist and are used, and which meet the requirements in terms of arrangement and equipment for their use in accordance with the provisions of the Law on Spas. Health spa resorts with their specific geographical conditions are often called climatic places in Serbia. In this regard, climate plays an essential role in the interpretation of health spa resorts, due to outdoor recreation, especially if it is assessed in the context of physiological processes in humans. The interaction between 
dynamically changing climatic conditions and physiological processes in man is the essence of the relationship between man and the environment. Since most of the recreation takes place outside, knowing the effects of climatic elements on humans during different stages of recreation is very important.

Determining extreme weather events from the aspect of human heat budget indices allows other meteorological parameters such as air humidity, wind velocity and solar radiation to be taken into account. According to McGregor \& Vanos (2015), environmental conditions that are potentially detrimental to human health occur both indoors and outdoors. For outdoor environments in particular, apart from temperature and humidity, wind and direct solar radiation have to be considered as well (Błażejczyk \& Kunert, 2011). Generated heat load can undermine the human body's ability to hold its core temperature within the range of optimal physiological achievement (McGregor \& Vanos, 2018). Climate extremes indices allow the assessment of changes in extreme weather and climate events. According to Jendritzky et al. (2012), heat stress describes such stress that acts on the human thermoregulatory system due to heat exchange between the body and its thermal environment considering clothing, too.

What can be important for this health spa resort regarding outdoor recreation and tourism, is its bioclimatic analysis which can indicate the existence of heat or cold stress. Since there is still no detailed bioclimatic analysis of this resort, the main task of this paper is to present a general overview of the annual and seasonal variability of the UTCI thermal stress and to focus on extreme heat stress, hot and cold.

\section{Study area}

The research area is located in Southeast Serbia in the central part of the Balkan Peninsula, particularly in the Vranje basin in the Morava-Vardar valley. Vranje basin is part of South Pomoravlje, $30 \mathrm{~km}$ long and $6 \mathrm{~km}$ wide with meridian orographic direction and includes an urban area of Vranje, (487 $\mathrm{m}$ a.s.l.), and the municipality of Vranjska Banja (380 $\mathrm{m}$ a.s.I.) (Fig. 1). It is the first extension within the complex valley of the South Morava where chines and structural basins alternate. Vranje with its surroundings is connected with the Vardar valley in the south, and with the Kosovo-Metohija basin in the southwest, allowing air to flow from the south. In the north and northeast, Vranje region is connected to the Leskovac basin, which provides continental currents to flow through the basin (Stamenković, 1995). The urban area of Vranje is located at the foot of several mountains up to 1950 m a.s.l. (Besna Kobila 1922 m a.s.I., Veliki Pešter 1946 m a.s.l., Patarica 1806 m a.s.l.). Particularly, the municipality of Vranjska Banja (Health Spa Resort) is located at the foothills of the Besna Kobila Mt. $10 \mathrm{~km}$ northeast of the City of Vranje, covering an area of $258 \mathrm{~km}^{2}$ (Denda et al. 2019). Vranjska Banja is a balneological centre with the hottest geothermal spring in Serbia, with discharge temperatures of $96^{\circ} \mathrm{C}$. The thermal springs of Vranjska Banja belong to the hydrogeothermal system formed in contact with and in the marginal zones of the Neogene granitoid intrusions where the reservoir rocks are granitoids, metamorphic and contact-metamorphic rocks, heavily fractured as a result of heating and cooling. According to its physicochemical characteristics, its waters belong to the category of sodium hydrocarbonate, sulfate fluoride and sulfate hypertherms. There is a considerable amount of gas dissolved hydrogen sulfide, which classifies this water in sulphide mineral waters (the most healing in balneotherapy view) (Milivojevic et al., 2005).

The meteorological data used in the study were acquired from the Republic Hydrometeorological Service of Serbia (Vranje weather station). The location of the weather station (433 $\mathrm{m}$ a.s.l.) in relation to the City of Vranje and Vranjska Banja can be seen on the map (Fig. 1). 


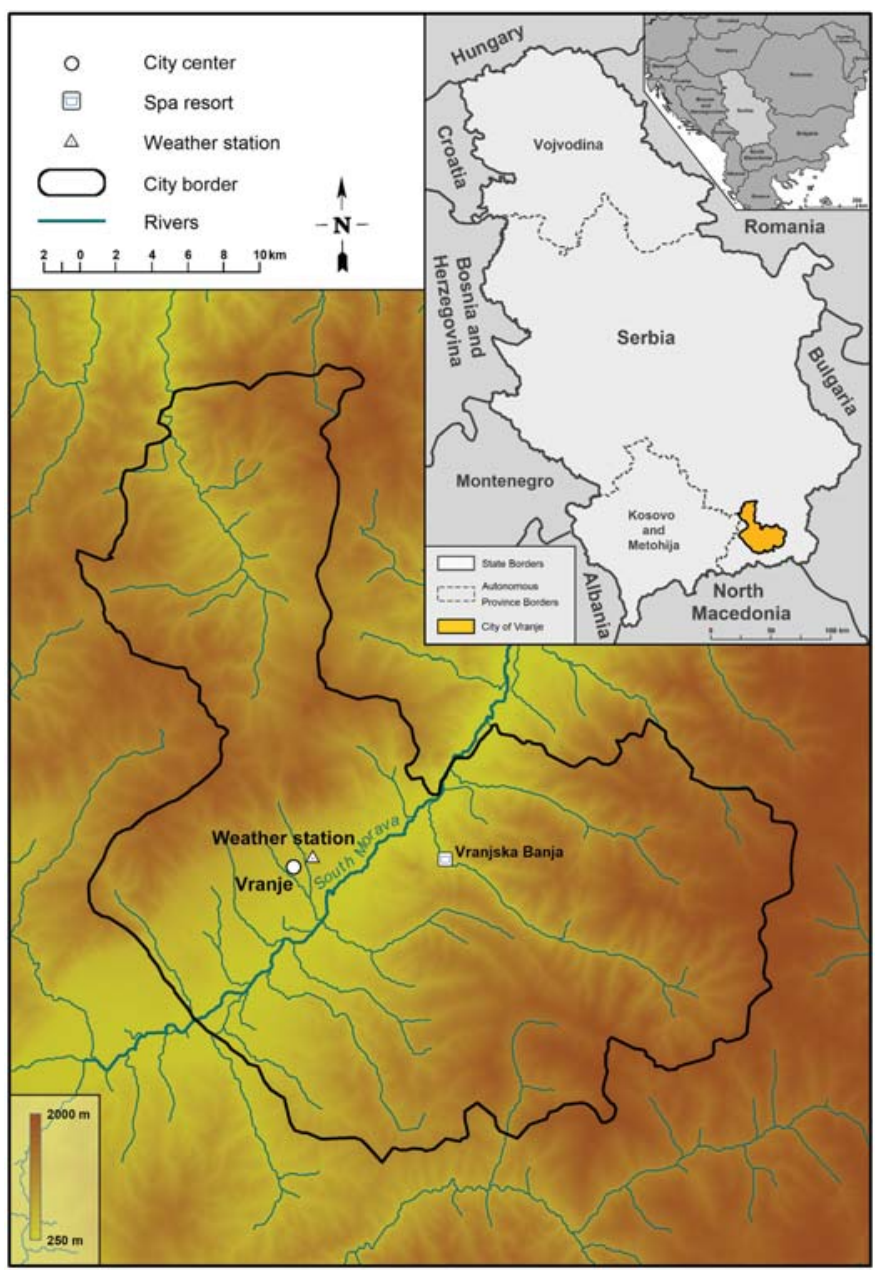

Figure 1. The territory of Vranje. The map was created in GIS GeoMedia Professional software

Majority of the Vranje basin area is elevated 501-1000 m a.s.I. (Tab. 1) while the weather station, Vranjska Banja and the City of Vranje are elevated up to $500 \mathrm{~m}$ a.s.l. The local climate is characterised by peculiarities formed between the modified Mediterranean and moderate continental climate, due to the influence of orography and relief. At the bottom of the Vranje basin and in the region of hills along the edge of the valley, spring occurs early and lasts for a short time. That is why late frosts are a common occurrence. Summers are warm, dry and long. Autumns are also long, warm and sunny, but dry. Winters in the Vranje valley are short and very
Table 1. Orographical structure of the Vranje basin

\begin{tabular}{|c|c|c|}
\hline $\begin{array}{c}\text { Altitudinal belt } \\
\text { [m a.s.l.] }\end{array}$ & $\begin{array}{c}\text { Total area } \\
{\left[\mathrm{km}^{2}\right]}\end{array}$ & $\begin{array}{c}\text { Area ratio } \\
{[\%]}\end{array}$ \\
\hline $250-500$ & 150.1 & 17.5 \\
$501-1000$ & 470.6 & 54.9 \\
$1001-1250$ & 176.1 & 20.5 \\
$>1250$ & 60.3 & 7.1 \\
\hline Total & 857.1 & 100.0 \\
\hline
\end{tabular}

[Altitude structure data were obtained by classification of the Digital Elevation Model (DEM)

Source: (NASA. 2000) Retrieved from http:// earthexplorer.usgs.gov/] 
mild with a slight snow cover. On the other hand, the peripheral hills and the mountainous region are rich in snow. Vranje basin climate mostly has temperate continental characteristics. According to the Köppen climate classification, it is categorised as Cfa (Kottek et al., 2006; Milovanović et al., 2017b).

\section{Material and Methods}

This study uses the methodological approach of the Universal Thermal Climate Index (UTCI) derived from the human heat budget model. It considers combined meteorological and physiological parameters describing thermal comfort relying on the evaluation of human energy balance. According to the definition, the UTCl is defined as the air temperature of the reference condition which would cause the same dynamic response of the physiological model as the actual conditions (Jendritzky et al., 2012). To facilitate interpretation and understanding of the UTCl index, the reference conditions for its calculations are defined in terms that are relevant to most people's experiences and relevant to the entire spectrum of climatic zones to which the UTCl applies. Therefore, physiological parameters, the metabolic rate (M) and the thermal properties of clothing (clothing insulation, permeability) are taken as universal constants in the model which implies the activity of a person who is outdoor and walking $4 \mathrm{kmh}^{-1}\left(1.1 \mathrm{~m} \cdot \mathrm{s}^{-1}\right)$ corresponding to the production of metabolic energy of 2.3 met (Havenith et al., 2012; Jendritzky et al., 2012). The following parameters are used for environment standard values (i) a wind speed (v) of $0.5 \mathrm{~m} \cdot \mathrm{s}^{-1}$ at $10 \mathrm{~m}$ height (approximately $0.3 \mathrm{~m} \cdot \mathrm{s}^{-1}$ at $1.1 \mathrm{~m}$ ), (ii) a mean radiant temperature (tmrt) equal to air temperature and (iii) vapour pressure (vp) that represents a relative humidity (f) of $50 \%$; at high air temperatures $\left(>29^{\circ} \mathrm{C}\right)$ (the reference humidity was taken to be constant at $20 \mathrm{hPa}$ (Błażejczyk, 2010b; Błażejczyk et al., 2010a, 2012, 2013). Particular ranges of the UTCl are categorised according to thermal stress (Tab. 2).

The meteorological data set from the period from 2000 to 2017 was recorded at the weather station in Vranje (Meteorological Yearbook, 2000-2018). We took into consideration hourly meteorological parameters (07:00, 14:00 CET) of air temperature $(t)$, air humidity (f), and wind speed (v) from the weather station for the calculation of particular UTCI thermal heat stress. The meteorological data set used in the study was retrieved from the Meteorological Yearbook for the period from 2000 to 2017 (Republic Hydrometeorological Service of Serbia, 2018) while the UTCI index was calculated by applying the BioKlima 2.6 software package (available at http://www.igipz.pan.pl/ Bioklima-zgik.html) and arranged as provided to the scale of thermal stress (Tab. 2).

The quantification of general human bioclimatic conditions is designed according to the reference thermal stress scale for the UTCI index providing the annual and seasonal frequencies of the UTCl index. Annual and seasonal averages are applied for distributions of mean monthly, mean seasonal and mean annual UTCI index values, along with mean monthly, mean seasonal and mean annual

Table 2. UTCI thermal stress classification

\begin{tabular}{|c|l|l|l|l|l|l|l|l|l|l|}
\hline $\begin{array}{r}\text { UTCl } \\
{\left[{ }^{\circ} \mathrm{C}\right]}\end{array}$ & $>46.0$ & $\begin{array}{l}38.1 \text { to } \\
46.0\end{array}$ & $\begin{array}{c}32.1 \text { to } \\
38.0\end{array}$ & $\begin{array}{c}26.1 \text { to } \\
32.0\end{array}$ & $\begin{array}{l}9.1 \text { to } \\
26.0\end{array}$ & $\begin{array}{l}0.1 \text { to } 9.0 \\
-13.0 \text { to } \\
0.0\end{array}$ & $\begin{array}{c}-27.0 \text { to } \\
-13.1\end{array}$ & $\begin{array}{l}-40.0 \text { to } \\
-27.1\end{array}$ & $<-40.0$ \\
\hline Stress & $\begin{array}{l}\text { extreme } \\
\text { heat } \\
\text { stress }\end{array}$ & $\begin{array}{l}\text { very } \\
\text { strong } \\
\text { heat } \\
\text { stress }\end{array}$ & $\begin{array}{l}\text { strong } \\
\text { heat } \\
\text { stress }\end{array}$ & $\begin{array}{l}\text { moder- } \\
\text { ate heat } \\
\text { stress }\end{array}$ & $\begin{array}{l}\text { no } \\
\text { thermal } \\
\text { stress }\end{array}$ & $\begin{array}{l}\text { slight } \\
\text { cold } \\
\text { stress }\end{array}$ & $\begin{array}{l}\text { moder- } \\
\text { ate cold } \\
\text { stress }\end{array}$ & $\begin{array}{l}\text { strong } \\
\text { cold } \\
\text { stress }\end{array}$ & $\begin{array}{l}\text { very } \\
\text { strong } \\
\text { cold } \\
\text { stress }\end{array}$ & $\begin{array}{l}\text { extreme } \\
\text { cold } \\
\text { stress }\end{array}$ \\
\hline Abbr. & EHS & VSHS & SHS & MHS & NTS & SLCS & MCS & SCS & VSCS & ECS \\
\hline
\end{tabular}

Source: (Błażejczyk et al., 2010) 
maximum and minimum of the UTCI specifically for hourly data at 7 and 14 CET. To determine the occurrence of thermal stress during the studied period, several measures were applied. First, we considered all situations with the occurrence of heat stress (HS) and cold stress (CS) for 7 and 14 CET. Heat stress refers to UTCl range $>32^{\circ} \mathrm{C}$ and cold stress refer to $\mathrm{UTCl}<-13^{\circ} \mathrm{C}$ (Tab. 3). Cold and heat stress days were extracted and presented year by year for 7 and 14 CET. In terms of the identification of very strong and extreme thermal stress during the observed period, daily threshold values in particular categories of very strong heat stress $\left(\mathrm{VSHS}>38^{\circ} \mathrm{C}\right)$, very strong cold stress (VSCS $<-27^{\circ} \mathrm{C}$ ) and extreme cold stress $\left(\mathrm{ECS}<-40^{\circ} \mathrm{C}\right.$ ) were determined by dates at 7 and $14 \mathrm{CET}$, while very strong heat stress (VSHS $>38^{\circ} \mathrm{C}$ ) category at 7 CET does not occur. Extreme heat stress was not considered because such stress class did not occur. For identification of biothermal discomfort, a very strong heat stress event is specified, caused by the occurrence of 5 consecutive VSHS days (Pecelj et al., 2020) (Tab. 3).
The last stage of the research is an attempt to demonstrate the daily difference in the UTCI hourly values (diurnal UTCI change, dUTCI) and the temporal averages conducted for annual and seasonal analysis of dUTCl. Therefore, for more comprehensive fluctuation of the UTCl index, the difference of their hourly values in consecutive days was determined (dUTC $=\mathrm{UTCl}_{14}-\mathrm{UTCl}_{07}$ ). Depending on the difference, the days with two categories of diurnal UTCl changes are, namely: $\mathrm{dUTCl}<0$ (increasing cold stress) and $\mathrm{dUTCl}>0$ (increasing heat stress). Due to the daily difference between the hourly index values, dUTCI progress by months and years was analysed by two categories: increasing cold and increasing heat stress (Tab. 3).

\section{Results}

\section{Annual and seasonal distribution of UTCI thermal stress categories}

The results are presented by the annual and seasonal distribution of UTCI stress classes specifically for the morning (7 CET) and midday (14 CET). The use of stacked chart was

Table 3. UTCl stress categories defined and considered in the study

\begin{tabular}{|c|c|}
\hline Thermal stress & Definition \\
\hline $\begin{array}{l}\mathrm{UTCl}_{14 \mathrm{~h}} \text { heat stress } \\
\mathrm{UTCl}_{14 \mathrm{~h}} \text { cold stress } \\
\mathrm{UTCl}_{7 \mathrm{~h}} \text { cold stress }\end{array}$ & $\begin{array}{l}>32^{\circ} \mathrm{C} \\
<-13^{\circ} \mathrm{C} \\
<-13^{\circ} \mathrm{C}\end{array}$ \\
\hline Very strong thermal stress & Definition \\
\hline $\begin{array}{l}\text { UTCI }_{\text {VSHS14h }} \\
\text { UTCI }_{\text {vSCSTh }} \\
\text { UTCI VSCS14h } \\
\text { UTCI VSHSE14h }\end{array}$ & $\begin{array}{c}\geq 38^{\circ} \mathrm{C} \\
-27^{\circ} \mathrm{C} \text { to }-40^{\circ} \mathrm{C} \\
-27^{\circ} \mathrm{C} \text { to }-40^{\circ} \mathrm{C} \\
\geq 38^{\circ} \mathrm{C}, 5 \text { or more days in a row }\end{array}$ \\
\hline Extreme thermal stress & Definition \\
\hline $\begin{array}{l}\text { UTCl }_{\text {ECSTh }} \\
\text { UTCl } \\
\text { ECS14h }\end{array}$ & $\begin{array}{l}<-40^{\circ} \mathrm{C} \\
<-40^{\circ} \mathrm{C}\end{array}$ \\
\hline Diurnal UTCI change (dUTCI) & Definition \\
\hline $\begin{array}{l}\mathrm{dUTCl} \\
\text { Increasing heat stress } \\
\text { Increasing cold stress }\end{array}$ & $\begin{array}{c}\mathrm{UTCl}_{14 \mathrm{~h}}-\mathrm{UTCl}_{7 \mathrm{~h}} \\
\mathrm{dUTCl}>0 \\
\mathrm{dUTCl}<0\end{array}$ \\
\hline
\end{tabular}


considered necessary to demonstrate the frequency (\%) of days with certain UTCI classes. For 7 CET no thermal stress is the most represented UTCl category during the year, especially in spring and autumn. Then, moderate heat stress occurs in the summer period, while generally cold stress is less indicated with all subcategories (Fig. 2). The annual UTCl distribution at 14 CET has less no thermal stress in relation to the total
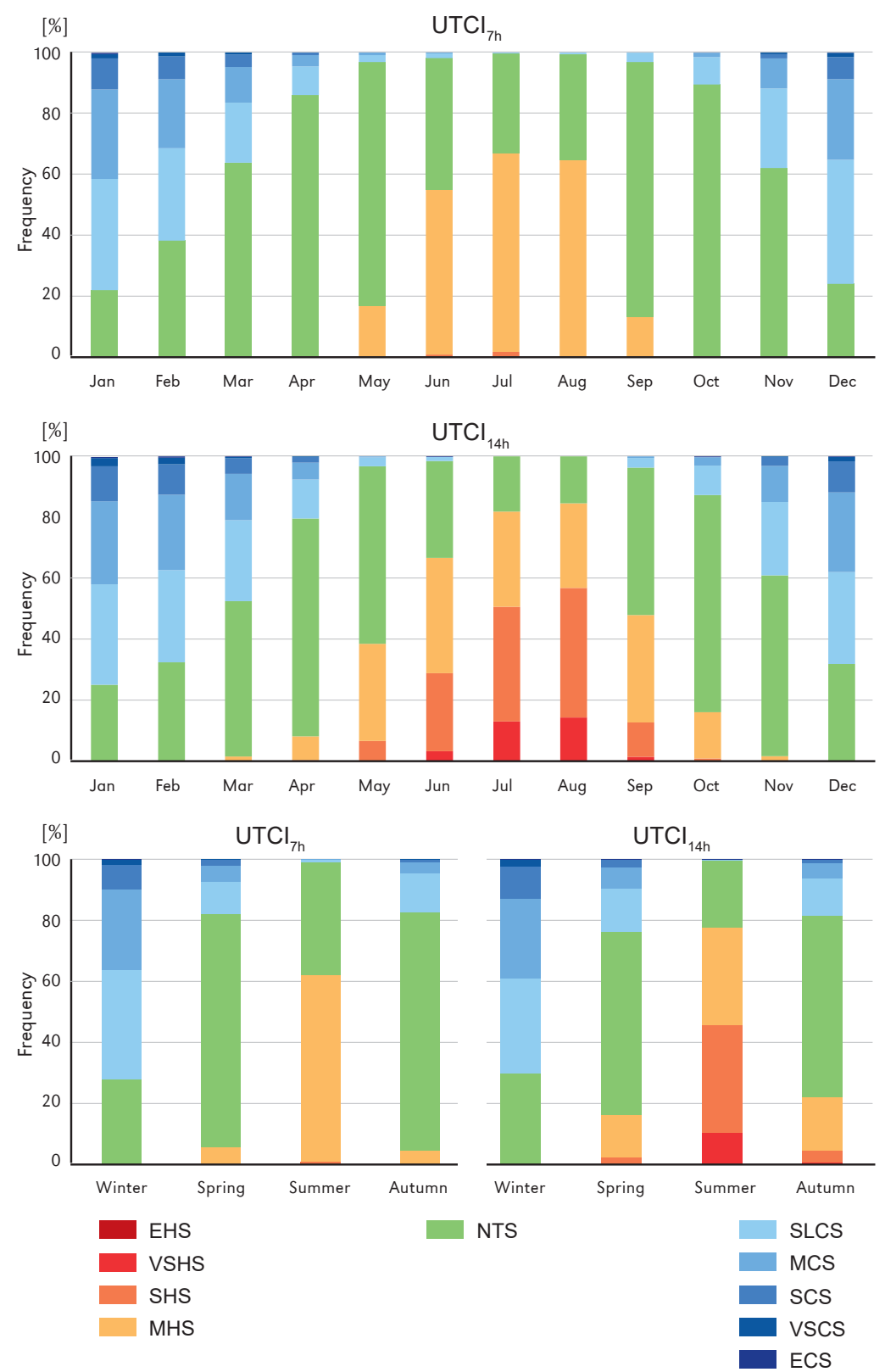

Figure 2. Annual and seasonal frequency (\%) of days with different UTCI thermal stress categories in the morning (7 CET) and midday (14 CET), Vranje, 2000-2017 
categories because the heat stress occurs more in the summer season, especially strong heat stress and very strong heat stress. There is no significant difference in cold stress for both morning and midday UTCl values. Regarding the seasonal distribution of UTCI, spring and autumn are generally without thermal stress at 7 CET. During winter and summer seasons, days without thermal stress occur despite the dominance of heat stress in summer and cold stress in winter. The UTCI stress categories at 14 CET are similarly distributed during winter and spring, while the total share of UTCl stress categories is different in summer and autumn if compared to that at 7 CET (Fig. 2).

Average annual values of $\mathrm{UTCl}$ are $14.8^{\circ} \mathrm{C}$ (morning) and $16.2^{\circ} \mathrm{C}$ (midday) referring to no thermal stress, while average annual maximums of $\mathrm{UTCl}$ are $23.6^{\circ} \mathrm{C}(7 \mathrm{CET})$ and $25.9^{\circ} \mathrm{C}$ (14 CET) referring to no thermal stress as well, but close to moderate heat stress and average annual minimums of $\mathrm{UTCl}$ are $-2^{\circ} \mathrm{C}$ (morning) and $-7.9^{\circ} \mathrm{C}$ (midday) referring to moderate cold stress (Tab. 4).
Concerning the mean monthly UTCl, the highest value is in July $26.6^{\circ} \mathrm{C}$ (7 CET) and $31.4^{\circ} \mathrm{C}(14 \mathrm{CET})$, and the lowest in January $0^{\circ} \mathrm{C}$ (morning) and $0.4^{\circ} \mathrm{C}$ (midday). The mean maximum UTCl in July is $31.4^{\circ} \mathrm{C}$ (7 CET) and $40.2^{\circ} \mathrm{C}(14 \mathrm{CET})$ referring to strong heat stress while the mean maximum $\mathrm{UTCl}$ in January is $14.9^{\circ} \mathrm{C}(7 \mathrm{CET})$ and $17^{\circ} \mathrm{C}(14 \mathrm{~h} \mathrm{CET})$. On the other hand, the mean minimum UTCI in July is $16.8^{\circ} \mathrm{C}$ (morning) and $18.7^{\circ} \mathrm{C}$ (midday) without thermal stress and mean minimum UTCI in January is $-22.9^{\circ} \mathrm{C}$ (7 and 14 CET) which refer to strong cold stress.

Seasonally, the average UTCl in spring and autumn is not quite different at 7 CET and amounts to $15.5^{\circ} \mathrm{C}$ and $15.7^{\circ} \mathrm{C}$, while the average $\mathrm{UTCl}$ in autumn is slightly higher at 14 CET. Moreover, the average UTCImax in spring $\left(24.2^{\circ} \mathrm{C}\right)$ and autumn $\left(23.9^{\circ} \mathrm{C}\right)$ indicates no thermal stress with 0.3 degrees of difference at 7 CET, while the average UTCImax in spring $\left(28.4^{\circ} \mathrm{C}\right)$ is 4.5 degrees higher in autumn $\left(23.9^{\circ} \mathrm{C}\right)$ at $14 \mathrm{CET}$. The average UTCImin spring $\left(-3.1^{\circ} \mathrm{C}\right)$ and autumn $\left(-3.0^{\circ} \mathrm{C}\right)$ at 7 CET are three degrees colder than the average

Table 4. Mean monthly and mean annual UTCI, UTCImax and UTCImin at 7 and 14 CET, Vranje 2000-2017

\begin{tabular}{|l|r|r|r|r|r|r|r|r|r|r|r|r|r|}
\hline Average $\left[{ }^{\circ} \mathrm{C}\right]$ & \multicolumn{1}{|c|}{ Jan } & \multicolumn{1}{|c|}{ Feb } & Mar & Apr & May & Jun & Jul & Aug & Sep & Oct & Nov & Dec & Year \\
\hline UTCl $_{7 \mathrm{~h}}$ & 0.4 & 3.6 & 8.9 & 15.9 & 21.8 & 25.2 & 26.6 & 26.0 & 21.5 & 16.3 & 9.3 & 1.7 & 14.8 \\
UTCl $_{14 \mathrm{~h}}$ & 0.0 & 2.1 & 7.9 & 15.5 & 23.3 & 28.3 & 31.4 & 31.9 & 24.6 & 18.2 & 9.9 & 2.0 & 16.2 \\
UTCImax $_{7 \mathrm{~h}}$ & 14.9 & 16.3 & 20.5 & 24.1 & 27.9 & 30.7 & 31.4 & 30.5 & 27.3 & 24.2 & 20.2 & 14.9 & 23.6 \\
UTCImax $_{14 \mathrm{~h}}$ & 17.0 & 19.7 & 23.8 & 28.4 & 33.0 & 38.0 & 40.2 & 40.2 & 34.8 & 30.2 & 23.4 & 18.2 & 25.9 \\
UTCImin $_{\text {7h }}$ & -22.9 & -17.9 & -15.8 & -1.0 & 7.5 & 12.5 & 16.8 & 15.5 & 9.9 & 1.2 & -10.4 & -20.0 & -2.0 \\
UTCImin $_{14 \mathrm{~h}}$ & -22.9 & -20.4 & -12.9 & -4.4 & 8.2 & 15.4 & 18.7 & 17.8 & 10.2 & 0.8 & -10.9 & -20.6 & -7.9 \\
\hline
\end{tabular}

Table 5. Mean seasonal UTCI, UTCImax and UTCImin at 7 CET and 14 CET, Vranje 2000-2017

\begin{tabular}{|l|c|c|c|c|}
\hline \multicolumn{1}{|c|}{ Variable } & \multicolumn{4}{|c|}{ Seasons } \\
\hline \multicolumn{1}{|c|}{ Average $\left[{ }^{\circ} \mathrm{C}\right]$} & Winter (DJF) & Spring (MAM) & Summer (JJA) & Autumn (SON) \\
\hline UTCl $_{7 \mathrm{~h}}$ & 1.7 & 15.5 & 25.9 & 15.7 \\
UTCl $_{14 \mathrm{~h}}$ & 1.4 & 15.6 & 30.5 & 17.6 \\
UTCImax $_{7 \mathrm{~h}}$ & 15.4 & 24.2 & 30.9 & 23.9 \\
UTCImax $_{14 \mathrm{~h}}$ & 18.3 & 28.4 & 39.5 & 29.3 \\
UTCImin $_{7 \mathrm{~h}}$ & -20.3 & -3.1 & 14.9 & 0.2 \\
UTCImin $_{14 \mathrm{~h}}$ & -21.3 & -3.0 & 17.3 & 0.0 \\
\hline
\end{tabular}


UTCImin spring $\left(0.2^{\circ} \mathrm{C}\right)$ and autumn $\left(0^{\circ} \mathrm{C}\right)$ at 14 CET indicating moderate cold stress for both measurements, morning and midday (Tab. 5). When analysing the seasonality of the phenomenon, three regularities are observed: summer differs significantly (astronomical factor), similar values in the spring and autumn season (slightly higher values in the autumn) and winter with slight differences but lower values than the spring and autumn seasons.

\section{A general assessment of heat and cold stress}

Regarding $\mathrm{UTCl}$ heat stress $\left(\mathrm{UTCl}>32^{\circ} \mathrm{C}\right)$ and $\mathrm{UTCl}$ cold stress $\left(\mathrm{UTCl}<-13^{\circ} \mathrm{C}\right)$ their frequencies were analysed year after year for the period 2000-2017 (Fig. 3). There is a notable decrease in the number of days with cold stress and an increase in the number of days with heat stress, especially in the last ten years. Significantly less cold stress days have been observed since 2007. In the first nine years, cold stress appeared in March, and sometimes in April. The most significant number of days with cold stress (18 days) was recorded in December 2001, followed by February 2003 (16 days). On a monthly basis, the greatest frequency of cold stress days occurs in January. However, the number of days with cold stress decreases. For instance, in 2000, 2001 and 2004, the number of days with cold stress was equal or above 10, while the following years had less number of days with cold stress. For the last 10 years, there have only been a few days with cold stress.

The most frequent heat stress occurs in August and July, as expected. However, there has been a significant increase in the number of days with heat stress since 2007. For example, heat stress with a frequency of 20 days or more appears in July and August while 10 or more days appear in September. The largest number of heat stress days has been observed in July with a maximum of 26 days in 2012, then August with a maximum of 26 days in 2015. Otherwise, both months (July and August) have been almost constantly affected by heat stress during 2003, 2007, 2008, 2010, 2011, 2012, 2015 and 2017 since there were more than 20 days with heat stress (Fig. 3). No less noticeable was the increase of days with heat stress in June 2012 and 2017 with 19 and 16 days, respectively, and even in September 2011, 2012 and 2015 with 12 and 11 days, respectively.

In terms of the number of months affected by heat stress, 2012 stands out during the period from April till October. Although October is a relatively warm month, sometimes above the monthly average, the results show that heat stress occurred during 3 years of the observed period only, namely: 2006, 2009 and 2012.

For the morning hours, monthly frequency of the number of cold stress days is similar to those at 14 CET up to 2007. The greatest cold stress occurred in 2000, 2001, 2012 and 2004 with 10, 12 and 11 days with UTCl below $-13^{\circ} \mathrm{C}$, respectively. Thereafter, cold waves of 9 days were recorded in January and February, respectively. During other years, cold stress occurred up to 2 or 3 days in any of the winter months (Fig. 4). Although the winter of 2012 was cold with a few cold waves (Unkašević \& Tošić, 2015), however, biothermal conditions were slightly softer than the climate conditions defined based on meteorological parameters, most often at the minimum and maximum air temperatures. This can also be attributed to the influence of radiation which is the highest in midday hours.

\section{Very strong and extreme thermal stress}

To identify the occurrences of extreme thermal stress, both heat and cold, daily UTCI categories of very strong heat stress VSHS $\left(\mathrm{UTCl}_{\mathrm{VSHS}} 38-46^{\circ} \mathrm{C}\right)$, very strong cold stress VSCS (UTCl ${ }_{\text {vsCS }}-27$ to $-40^{\circ} \mathrm{C}$ ) and extreme cold stress ECS ( $\left.\mathrm{UTCl}_{\mathrm{ECS}}<-40^{\circ} \mathrm{C}\right)$ were determined for 7 and 14 CET. Very strong heat stress (VSHS) at 7 CET and extreme heat stress (EHS) at 7 and 14 CET does not occur. Episodes of daily extreme thermal stress with very strong heat stress $\left(\mathrm{UTCl}_{\mathrm{VSHS}}\right)$ were 


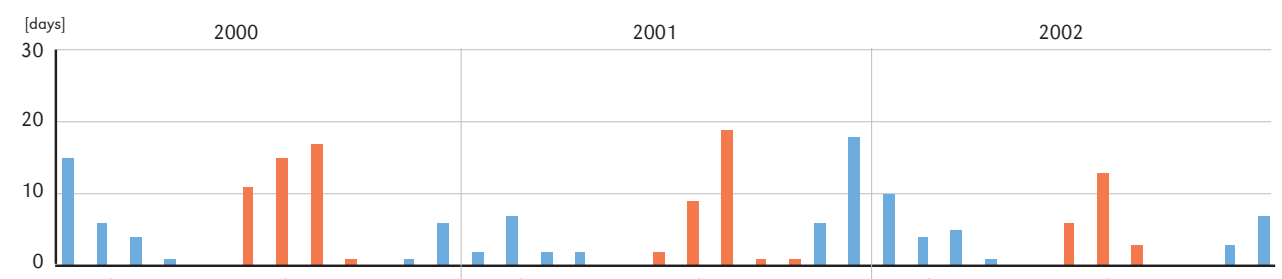
Jan Feb Mar Apr May Jun Jul Aug Sep Oct Nov Dec Jan Feb Mar Apr May Jun Jul Aug Sep Oct Nov Dec Jan Feb Mar Apr May Jun Jul Aug Sep Oct Nov Dec

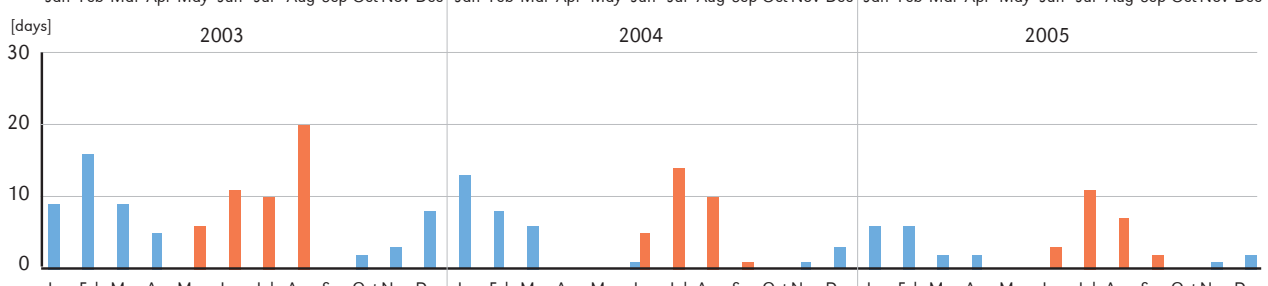

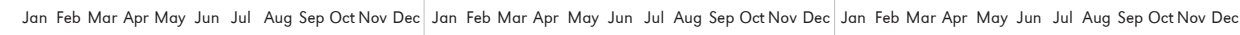

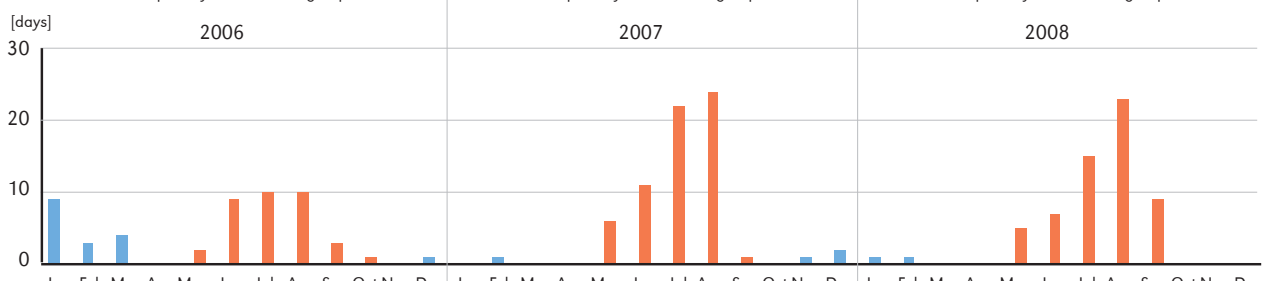
Jan Feb Mar Apr May Jun Jul Aug Sep OctNov Dec Jan Feb Mar Apr May Jun Jul Aug Sep Oct Nov Dec Jan Feb Mar Apr May Jun Jul Aug Sep Oct Nov Dec

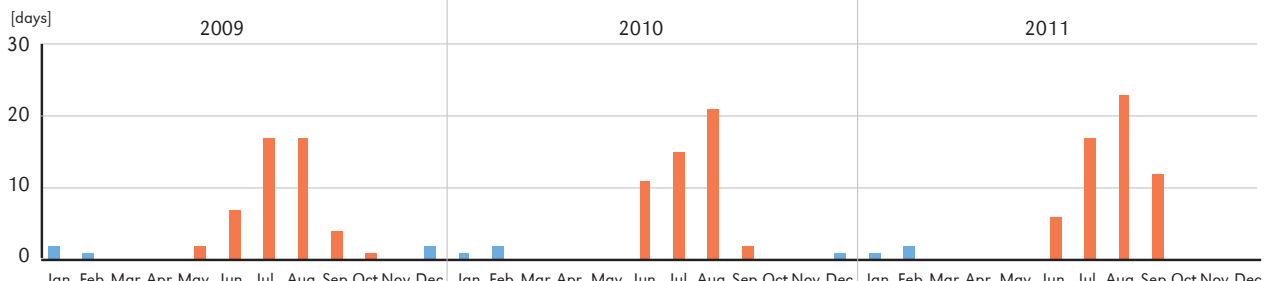
Jan Feb Mar Apr May Jun Jul Aug Sep OctNov Dec Jan Feb Mar Apr May Jun Jul Aug Sep Oct Nov Dec Jan Feb Mar Apr May Jun Jul Aug Sep Oct Nov Dec

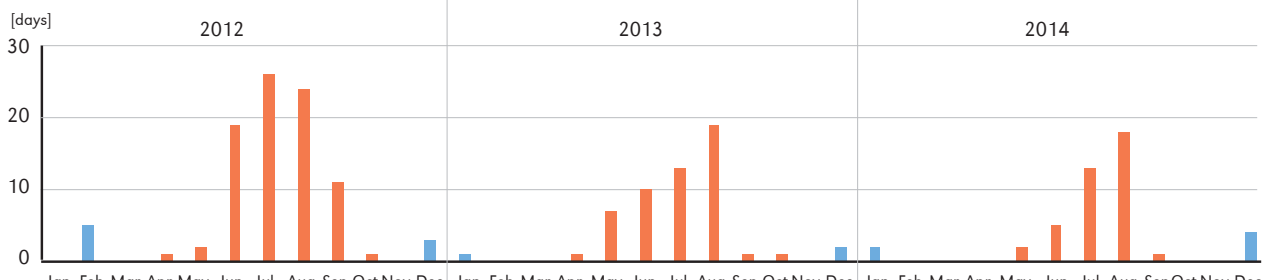
Jan Feb Mar Apr May Jun Jul Aug Sep OctNov Dec Jan Feb Mar Apr May Jun Jul Aug Sep Oct Nov Dec Jan Feb Mar Apr May Jun Jul Aug SepOct Nov Dec

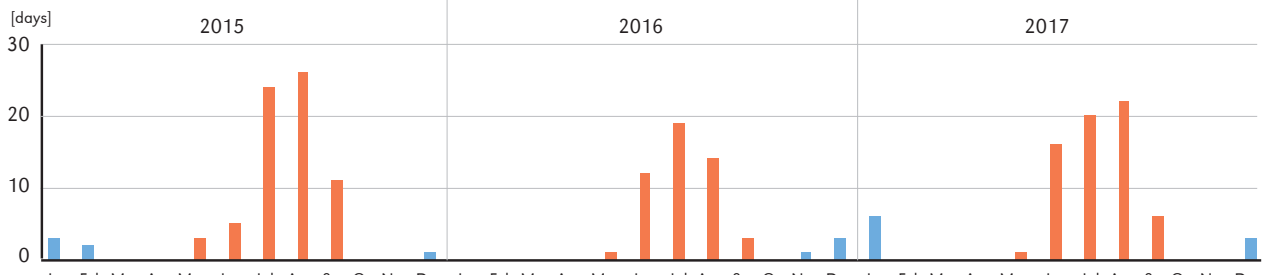

Jan Feb Mar Apr May Jun Jul Aug Sep Oct Nov Dec Jan Feb Mar Apr May Jun Jul Aug Sep Oct Nov Dec Jan Feb Mar Apr May Jun Jul Aug SepOct Nov Dec

$$
\mathrm{UTCl}_{14 \mathrm{~h}} \text { cold stress }
$$

$\mathrm{UTCl}_{14 \mathrm{~h}}$ heat stress

Figure 3. Monthly frequency of days with cold stress and heat stress at 14 CET, Vranje 2000-2017 (x-axis represents months in a year and $y$-axis represents the number of days) 


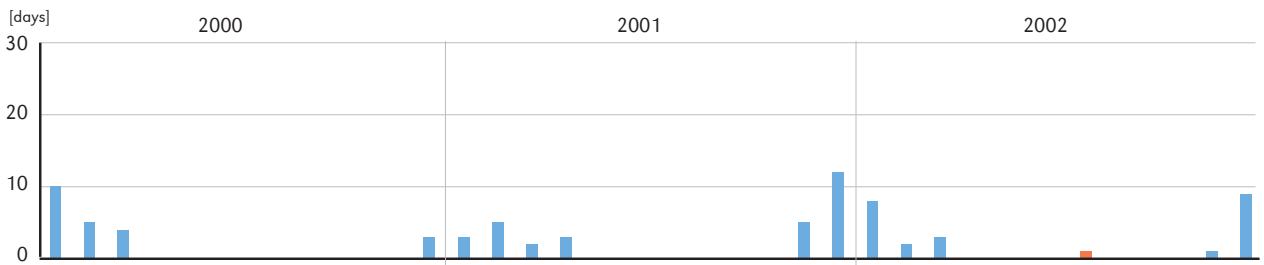
Jan Feb Mar Apr May Jun Jul Aug Sep OctNov Dec Jan Feb Mar Apr May Jun Jul Aug Sep Oct Nov Dec Jan Feb Mar Apr May Jun Jul Aug Sep Oct Nov Dec

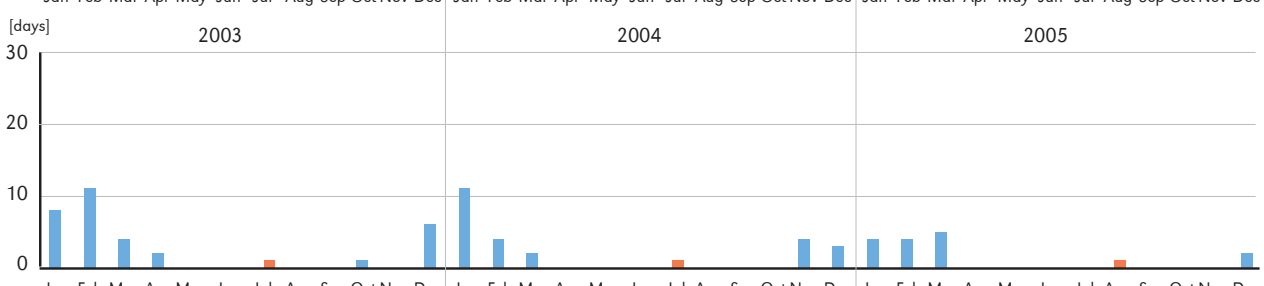
Jan Feb Mar Apr May Jun Jul Aug Sep OctNov Dec Jan Feb Mar Apr May Jun Jul Aug Sep Oct Nov Dec Jan Feb Mar Apr May Jun Jul Aug Sep Oct Nov Dec

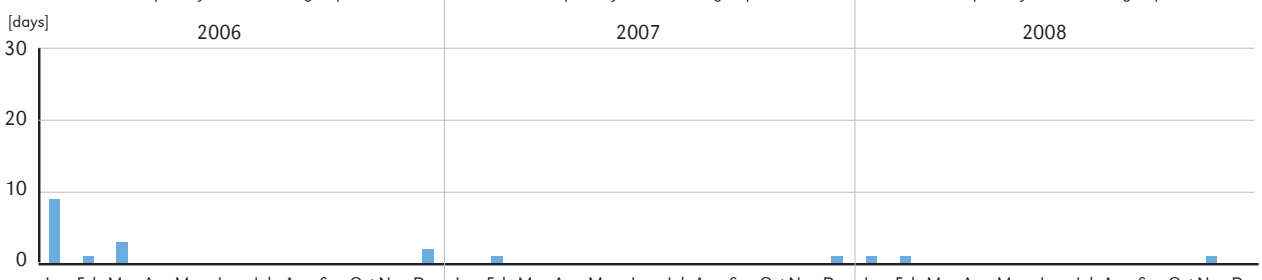
Jan Feb Mar Apr May Jun Jul Aug Sep Oct Nov Dec Jan Feb Mar Apr May Jun Jul Aug Sep Oct Nov Dec Jan Feb Mar Apr May Jun Jul Aug Sep Oct Nov Dec
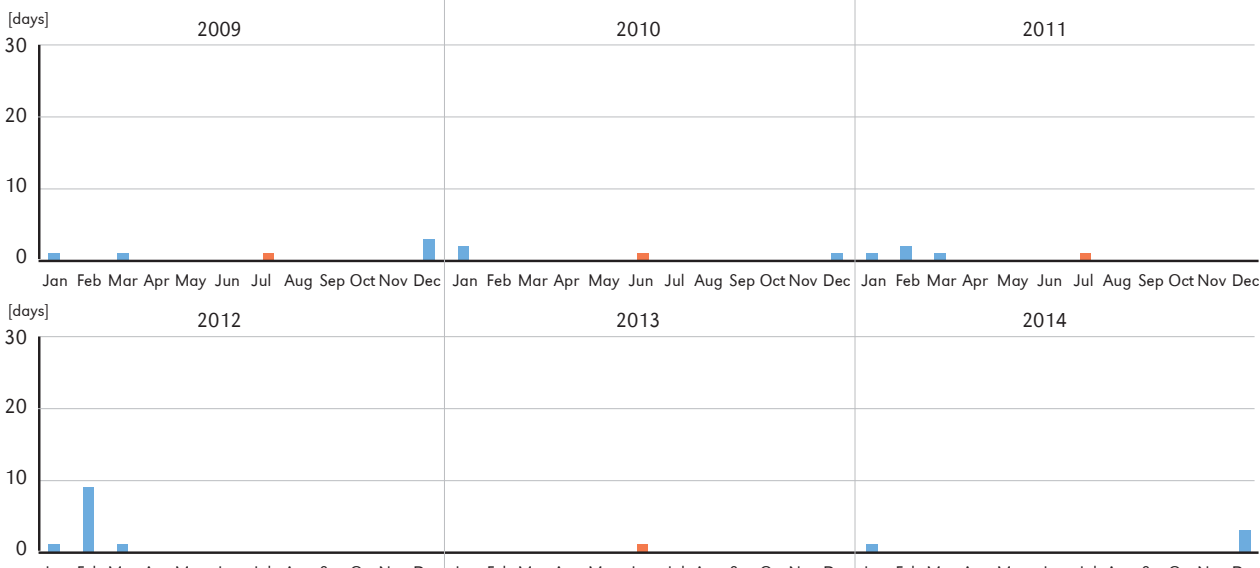

Jan Feb Mar Apr May Jun Jul Aug Sep OctNov Dec Jan Feb Mar Apr May Jun Jul Aug Sep Oct Nov Dec Jan Feb Mar Apr May Jun Jul Aug SepOctNov Dec

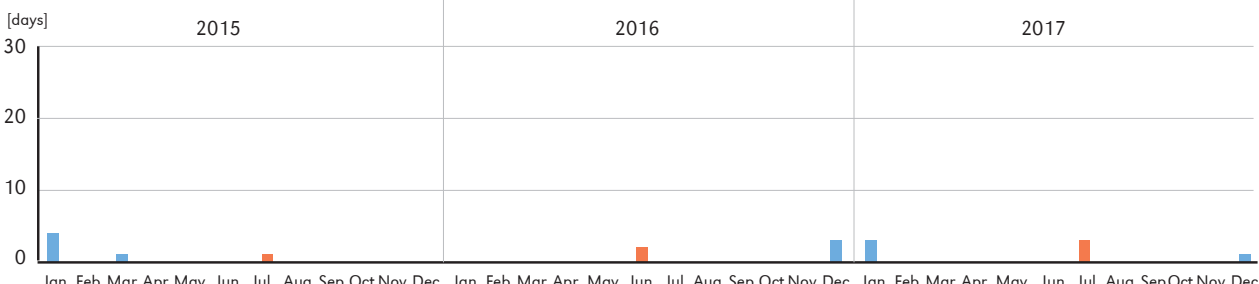

Jan Feb Mar Apr May Jun Jul Aug Sep Oct Nov Dec Jan Feb Mar Apr May Jun Jul Aug Sep Oct Nov Dec Jan Feb Mar Apr May Jun Jul Aug SepOct Nov Dec

$$
\mathrm{UTCl}_{7 \mathrm{~h}} \text { cold stress }
$$

$\mathrm{UTCl}_{7 \mathrm{~h}}$ heat stress

Figure 4. Monthly frequency of days with cold stress and heat stress at 7 CET, Vranje 2000-2017 (x-axis represents months in a year and y-axis represents the number of days) 
determined by years at 14 CET (Fig. 5), while daily extreme thermal stress with very strong cold stress (UTCI vSCS $_{\text {S }}$ ) and extreme cold stress $\left(U T C I_{E C S}\right)$ was determined by years at 7 and 14 CET (Fig. 6).

The $x$-axis in Figure 5 shows the total number of days (dates) with specific $\mathrm{VSHS}_{14 \mathrm{~h}}$ category during a certain year, and the axis is scaled non-linearly. The dates when VSHS appears are combined into one date matrix. If more than one parameter (e.g. VSHS) appears for a given date, the date is counted once. Further on, the $x$-axis is divided by the number of dates, and each measurement has its own slot on the $x$-axis. The $y$-axis in Figure 5 shows the VSHS category range of $38.2-45.9^{\circ} \mathrm{C}$ indicating recorded min and max VSHS values in the study. The dashed red line represents the average $\mathrm{UTCl}_{\mathrm{VSHS}}\left(39.8^{\circ} \mathrm{C}\right)$.

Observing the days with very strong heat stress $\left(\mathrm{UTCl}_{\mathrm{VSHS} 14 \mathrm{~h}} \geq 38^{\circ} \mathrm{C}\right.$ ), it can be noted that their frequency increased since 2007 (Fig. 5, red line). For instance, there were 20 days with VSHS in 2007, then 23 days in 2012 and 26 days in both 2015 and 2017. Although the frequency of days with VSHS increased since 2007, the highest UTCI was recorded on July 5, $2000\left(\mathrm{UTCl}_{\mathrm{VSHS} 14 \mathrm{~h}}=45.9^{\circ} \mathrm{C}\right)$ and July $24,2007\left(\mathrm{UTCl}_{\mathrm{VSHS} 14 \mathrm{~h}}=45.8^{\circ} \mathrm{C}\right)$. The highest $\mathrm{UTCl}_{\text {VSHS14h }}$ values were recorded in 2000, 2007 and 2017 at 14 CET (Fig. 5). Following that, it is observed that the number of days with a UTCI ${ }_{\text {VSHS }}$ value higher than the average $\left(39.8^{\circ} \mathrm{C}\right.$ ) increased after 2007 (Fig. 5).

The very strong heat stress most commonly occurs in July and August, but it should be pointed out that in the last ten years, the VSHS occurred in September. During 2011, 2012 and 2015, there were 11-12 days with heat stress. In particular, VSHS occurred in September starting in 2008 with 2 days, when the $\mathrm{UTCl}$ was $39.8^{\circ} \mathrm{C}$, up to 5 days in 2015. September was an extreme month in 2015 when the UTCl reached the maximum of $40.8^{\circ} \mathrm{C}$. Table 6 shows recorded VSHS in September from 2000-2017, which agrees with the finding that heatwaves began to appear in September in the last decade (Tomczyk, 2016).
It should be emphasised that in the last ten days of the observed period, VSHS occurred as extremely hot events of at least 5 consecutive days. In the warmest year of the observed period - 2007, 8 consecutive days with $\mathrm{UTCl}>38^{\circ} \mathrm{C}$ were recorded in July. Then, in August 2010, 5 consecutive days were observed. Furthermore, in July and August 2012, 5 and 6 consecutive days were observed, respectively, while in July 2015, an extremely hot wave with VSHS lasted for 8 days. Finally, in August 2017, they appeared twice, in the first half of August with 8 and 5 days. However, if the last two VSHS days of July and these 8 days in early August are taken into account, the total VSHS wave lasted for 10 consecutive days.

Regarding extremely cold stress, the number of days with very strong cold stress $\left(\mathrm{UTCl}_{\mathrm{vsC} 14 \mathrm{~h}} \leq-27^{\circ} \mathrm{C}\right)$ decreased during the studied period 2000-2017 which can be seen in Figure 6 (light blue line and blue line). Analogous to Figure 5, the x-axis in Figure 6 shows the total number of days (dates) with specific VSCS ${ }_{7 h}$, VSCS $_{14 h}$ and ECS during a certain year and the axis is scaled non-linearly. The dates when VSCS $_{7 \mathrm{~h}}$ VSCS $_{14 \mathrm{~h}}$ appeared are combined into one date matrix. If more than one parameter (e.g., VSCS and ECS) appears for a given date, the date is counted once. Further, the $x$-axis is divided by the number of dates, and each measurement has its own slot on the $x$-axis. The $y$-axis in Figure 6 shows the VSCS category range of -27 to $-40^{\circ} \mathrm{C}$ indicating recorded min and max VSCS and below $-40^{\circ} \mathrm{C}$, down to the minimum of UTCl, amounted $-54.9^{\circ} \mathrm{C}$ indicating ECS. The dashed light blue line represents the average UTCI $\left(-33.0^{\circ} \mathrm{C}\right)$ at $7 \mathrm{CET}$ that occurred during the observation period, while the dashed blue line represents the average $U \mathrm{UCI}_{\text {VsCS }}\left(-32.1^{\circ} \mathrm{C}\right)$ at 14 CET. Due to the smaller number of days with extreme cold stress (less than ten days), observations at 7 and 14 CET are shown by the purple dots (ECS7h) and the green dots (ECS14h) in the lower chart.

As seen in Figure 6, very strong cold stress VSCS occurred at both 7 and 14 CET until 2006 (Fig. 5, blue line and light blue line). 


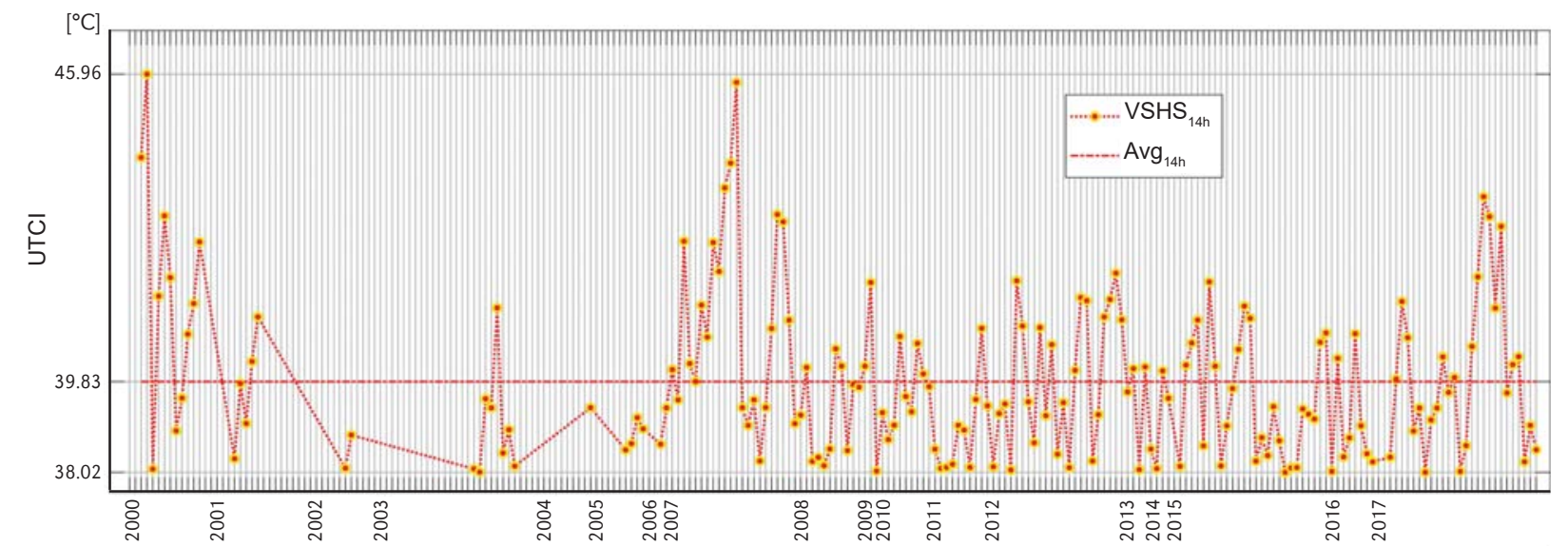

Figure 5. Days (dates) with very strong heat stress VSHS ${ }_{14 \mathrm{~h}}$ (red line) by years 2000-2017. The dashed red line is the average VSHS classes

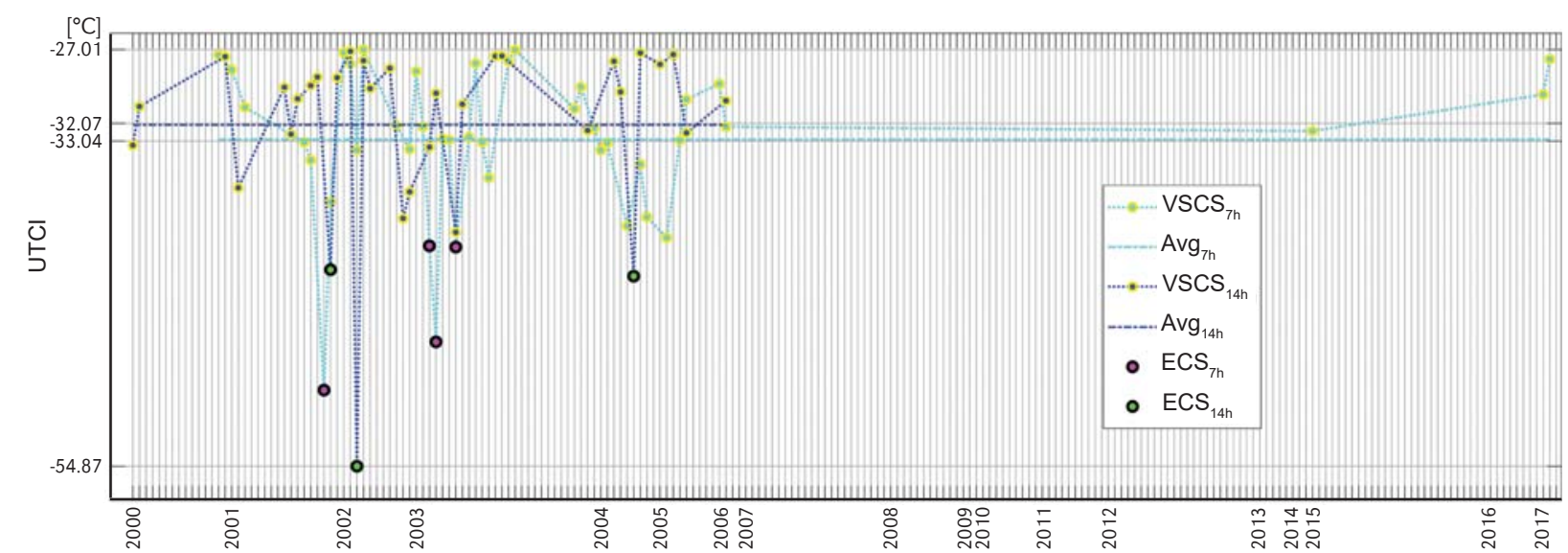

Figure 6. Days (dates) with very strong cold stress $\operatorname{VSCS}_{7 \mathrm{~h}}$ (light blue line), $\mathrm{VSCS}_{14 \mathrm{~h}}$ (blue line) and extreme cold stress $\mathrm{ECS}_{7 \mathrm{~h}}$ (purple dot) and ECS by years 2000-2017. The dashed lines are the average stress of each separated classes (VSCS ${ }_{7 \mathrm{~h}}$ - dashed light blue line and VSCS ${ }_{14 h}{ }^{-}$dashed blue line) $^{14 h}$ 
Table 6. Dates in September with very strong heat stress (VSHS, 38 to $46^{\circ} \mathrm{C}$ ), Vranje 2000-2017

\begin{tabular}{|c|c|c|c|c|c|c|c|c|}
\hline Date & $\begin{array}{c}\text { Sep 7, } \\
2008\end{array}$ & $\begin{array}{c}\text { Sep 9, } \\
2008\end{array}$ & $\begin{array}{c}\text { Sep 1, } \\
2015\end{array}$ & $\begin{array}{c}\text { Sep 2, } \\
2015\end{array}$ & $\begin{array}{c}\text { Sep 18, } \\
2015\end{array}$ & $\begin{array}{c}\text { Sep 19, } \\
2015\end{array}$ & $\begin{array}{c}\text { Sep 17, } \\
2015\end{array}$ & $\begin{array}{c}\text { Sep 17, } \\
2017\end{array}$ \\
\hline $\mathrm{UTCl}_{14 \mathrm{~h}}$ & $39.8^{\circ} \mathrm{C}$ & $39.7^{\circ} \mathrm{C}$ & $39.3^{\circ} \mathrm{C}$ & $39.2^{\circ} \mathrm{C}$ & $40.6^{\circ} \mathrm{C}$ & $40.8^{\circ} \mathrm{C}$ & $39.1^{\circ} \mathrm{C}$ & $38.5^{\circ} \mathrm{C}$ \\
\hline
\end{tabular}

At the end of the analysed period, VSCS occurred only up to 2 days, only at 7 CET (Fig. 6, light blue line). Extreme cold stress ECS occurs in the morning and midday hours in four years of the observation period. The longest ECS at 7 CET occurred in 2003, three times, while in other years it occurred once, with the last one for the given period in 2004 (Fig. 6, purple and green dots).

\section{Diurnal UTCI change (dUTCI)}

The last point of the research is the assessment of diurnal UTCl change (dUTCl) illustrated by UTCI differences between midday and morning hours $\left(\mathrm{UTCl}_{14 \mathrm{~h}}-\mathrm{dUTCl}_{7 \mathrm{~h}}\right)$. The assessment of diurnal UTCl changes shows days with increasing cold stress $(\mathrm{dUTCl}<0)$ and the days with increasing heat stress (dUTCl $>0$ ). The negative daily change in the UTCI is caused by a decrease in daily temperature during the day. This situation refers to a sudden change in weather caused by a quick decrease of atmospheric pressure which results in strong gusts of wind and rapid temperature declines during the day. On the other hand, the positive daily change in UTCl is related to typical air temperature course during the day, i.e. temperature rise during the day reaching a maximum of 2 to 5 hours after the local noon (depending on the season). The monthly number of days with negative dUTCI (increasing cold stress) and with positive dUTCI (increasing heat stress) are shown in Figure 7. A general overview of the dUTCI shows a record that was expected. Mostly days with increasing heat stress occur in summer months and the days with increasing cold stress - in winter months. However, there is a reduction in increasing cold stress days throughout the studied period. It has been particularly pronounced during the spring (March, April) and autumn (November) in the last ten years, where the number of days with increasing cold stress is replaced by the dominant number of days with increasing heat stress (Fig. 7). Excluding the summer months, the longest period with a positive dUTCI, mostly over 20 days is observed in May, September and October. At the same time, an increase in positive dUTCl reaching over 20 days is noted in November.

It has shown that the longest periods with positive dUTCl refer to years with mild winter. Even in January and December, during the relatively warm winters (2007, 2009, 2011, 2015 and 2016), more than 20 days were recorded with a positive dUTCl. For example, all months of 2007 except February had more days with positive dUTCI than with a negative one. Furthermore, in April and November, the number of days with positive dUTCl increased in the last ten years, while the number of days with a negative difference decreased. Despite the fluctuations from year to year because of various climate factors, the daily increase of heat stress ( $\mathrm{UUTCl}>0$ ) and the daily decreasing cold stress $(\mathrm{dUTCl}<0)$ can be identified, particularly in the last ten years.

The highest average monthly dUTCl is observed in August $\left(5.9^{\circ} \mathrm{C}\right)$ while the lowest one is in February $-1.5^{\circ} \mathrm{C}$. Average dUTCl, dUTCImax and dUTCImin were calculated for particular months, years and seasons based on daily $\mathrm{UTCl}$ change. Table 7 shows the negative average monthly dUTCI from January till April, while in other months average monthly dUTCI values are positive. It is seen that the average dUTCl in autumn months is positive, which is an effect of the increase in the number of days with positive diurnal changes. The average annual dUTCl is $1.5^{\circ} \mathrm{C}$. Annually, the frequency of the positive diurnal change (increasing heat stress) is longest than the frequency of the negative diurnal dUTCl change (increasing cold stress) which gives an annual difference of UTCl of $1.5^{\circ} \mathrm{C}$. 

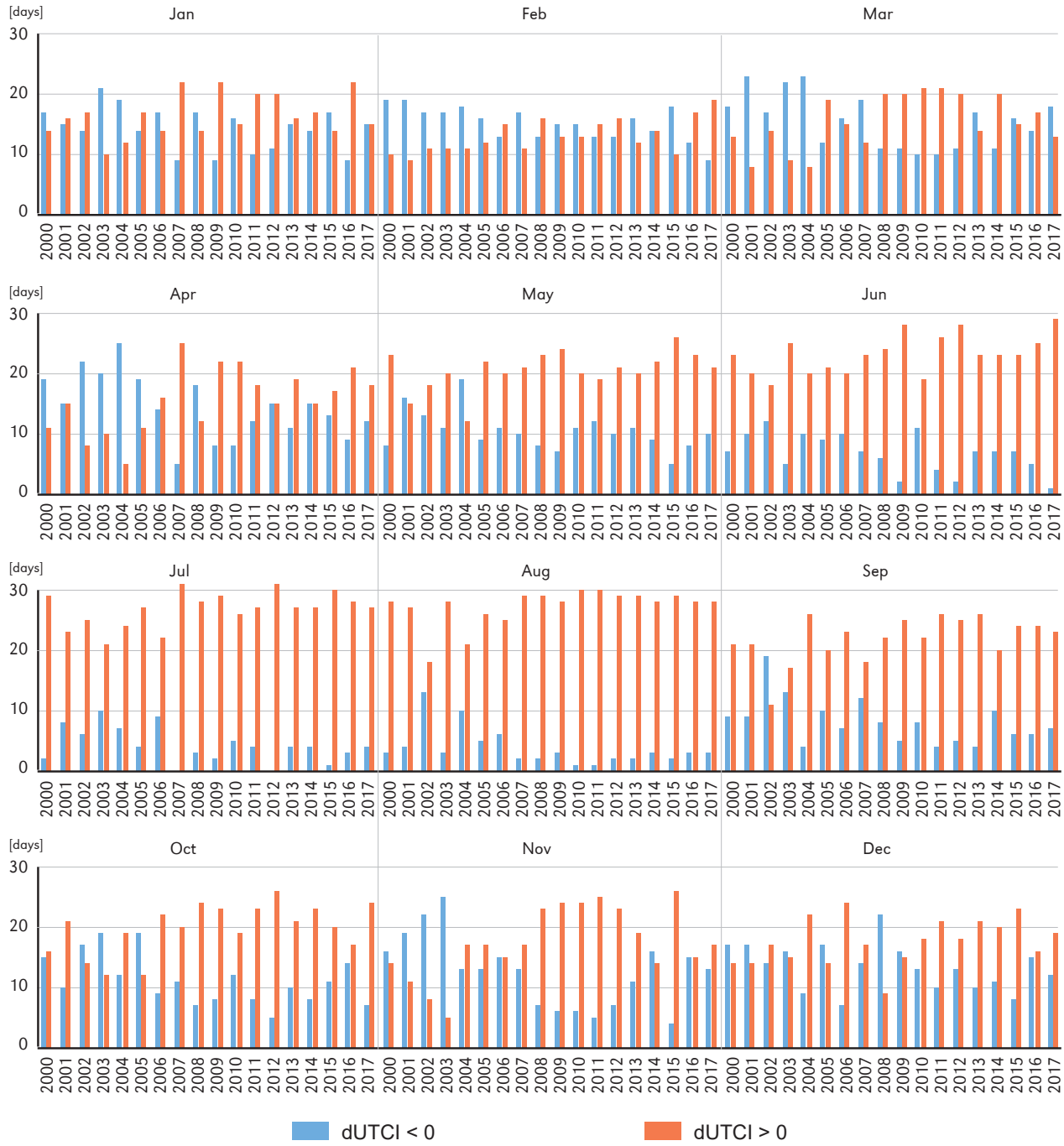

Figure 7. Monthly frequency of days with increasing heat stress ( $\mathrm{dUTCl}>0$ ) and with increasing cold stress (dUTCl <0), Vranje 2000-2017 (x-axis represents years of the observed period and y-axis represents the number of days)

Furthermore, table 7 illustrates the annual and monthly average of maximum dUTCl, together with the annual and monthly average of minimum dUTCl. The average annual maximum of $\mathrm{dUTCl}$ is $15^{\circ} \mathrm{C}$, and an average annual minimum of $\mathrm{dUTCl}$ is $-14.3^{\circ} \mathrm{C}$. The highest average monthly maximum is in January while the lowest is in June; otherwise, the highest average monthly minimum is in February and the lowest is in August.
Concerning the average seasonal distribution of $\mathrm{dUTCl}$, there is positive dUTCl in spring, summer and autumn while negative dUTCl is in winter (Tab. 8). The mean seasonal dUTCl maximum is almost equal in spring $\left(14.7^{\circ} \mathrm{C}\right)$ and autumn $\left(14.2^{\circ} \mathrm{C}\right)$. It is slightly lower in summer, while it is slightly higher in winter. The mean seasonal dUTCl minimum is the lowest in winter and significantly higher in summer. Unlike the mean seasonal 
Table 7. Monthly and annual average values of diurnal dUTCl change (dUTCl, dUTClmax and dUTCImin), Vranje 2000-2017

\begin{tabular}{|l|c|r|r|r|r|r|r|r|r|r|r|r|r|}
\hline dUTCl & Jan & Feb & Mar & Apr & May & Jun & July & Aug & Sep & Oct & Nov & Dec & Year \\
\hline avg & -0.4 & -1.5 & -0.8 & -0.4 & 1.6 & 2.8 & 4.8 & 5.9 & 3.2 & 2.0 & 0.6 & 0.3 & 1.5 \\
max & 18.9 & 17.5 & 16.9 & 15.1 & 12.3 & 12.2 & 12.6 & 14.1 & 13.2 & 13.8 & 13.8 & 17.4 & 15 \\
min & -20.6 & -22.0 & -21.7 & -16.1 & -12.1 & -7.8 & -5.8 & -5.4 & -11.6 & -11.5 & -17.6 & -19.5 & -14.3 \\
\hline
\end{tabular}

Table 8. Seasonal average values of diurnal dUTCl change (dUTCl, dUTCImax and dUTCImin), Vranje 2000-2017

\begin{tabular}{|l|c|c|c|c|}
\hline \multirow{3}{*}{ Variable } & \multicolumn{4}{|c|}{ Seasons } \\
\cline { 2 - 5 } & Winter (DJF) & Spring (MAM) & Summer (JJA) & Autumn (SON) \\
\hline dUTClavg & -0.5 & 0.1 & 4.5 & 1.9 \\
dUTCImax & 17.9 & 14.7 & 13.0 & 14.4 \\
dUTCImin & -20.7 & -16.6 & -6.4 & -13.6 \\
\hline
\end{tabular}

dUTCl maximum, the mean seasonal dUTCI minimum is lower in spring $\left(-16.6^{\circ} \mathrm{C}\right)$ than in autumn $\left(-13.6^{\circ} \mathrm{C}\right)$.

\section{Discussion and Conclusion}

The present study shows bioclimatic conditions of the Vranje region affirmed as a health spa resort in Serbia. The paper presents a general overview of the annual and seasonal variability of UTCI index, for the period 2000-2017, representing thermal stress with an emphasis on extreme biothermal conditions, more precisely extreme heat and cold stress. Research indicates a general decrease of cold stress and the general increase of heat stress for the region of Vranje. For daily $\mathrm{UTCl}_{14 \mathrm{~h}}$ values, the number of days with very strong heat stress (VSHS) increases, while the number of days with very strong cold stress (VSCS) decreases. Similar results were obtained analysing daily maximum and minimum temperature in the Carpathian region of Romania (Croitorua \& Piticarb, 2013) or western Germany (Hundecha \& Bardossi, 2005). In Vranje, seasonal variability can be observed, with maximum intensity during extreme seasons (summer and winter) and slightly higher intensity during autumn. An analysis of the UTCI index shows significant differences in the level of stress in the seasonal distribution. Although there is a decrease in cold stress in the observed period, it is required to point out the cold waves that appeared in Serbia and the Balkan Peninsula in 2012 and 2017 (Unkašević \& Tošić, 2015; Anagnostopoulou et al., 2017). According to Unkašević and Tošić (2015), the longest cold wave was registered in Vranje during 2012 and lasted for 18 days. As reported by Tolika et al. (2014), the synoptic model of the cold event in January 2017 was similar to that in January-February 2012. Explaining significant snowfalls and low temperature in the southern Balkans during that cold event is an extension of the Siberian anticyclone towards Scandinavia blocking the western circulation and therefore forcing arctic air to move towards the equator (Tolika et al., 2014). Following the strong winter in February 2012, the Balkan Peninsula and the south-east of Europe faced the hottest summer and one of the worst droughts in nearly 40 years (Unkašević \& Tošić, 2015). Although the winter of 2012 was cold with a few cold waves, biothermal conditions were slightly softer (still with cold stress) than climatic conditions defined by meteorological parameters, most often at air temperatures minimum and maximum. That could be attributed to the radiation, and the physiological 
parameters such as metabolic rate and the clothing insulation on biothermal sensation, which are considered when calculating the UTCl index. Anyway, atmospheric circulation is an important factor shaping the conditions, particularly in the case of conditions causing strong stress for the human organism (Błażejczyk \& Twardosz, 2010; Tomczyk \& Owczarek, 2019).

Besides the frequency of days with very strong heat stress over $40^{\circ} \mathrm{C}$ increased since 2007 (14 days). Similar results were obtained for the northern part of Serbia where the number of days above particular thresholds increased along with a number of heatwaves per year (Basarin et al., 2016, 2018). Still, the maximum UTCl values were recorded in 2000 $\left(45.9^{\circ} \mathrm{C}\right)$ and $2007\left(45.8^{\circ} \mathrm{C}\right)$. Since 2007 , there were no greater UTCI than the recorded maximum, but the frequency of $\mathrm{UTCl}_{14 \mathrm{~h}} \mathrm{VSHS}$ days $\left(\mathrm{UTCl}>38^{\circ} \mathrm{C}\right)$ increased significantly. In a recent study on climate indices based on extreme temperatures for Serbia in relation to cold and hot extremes based on linear regression analysis, the ratio of intense events and changes in daily temperature was investigated for Vranje as well, where the longest heatwave of 13 days was recorded in the summer of 2012 while the maximum severity of the index was recorded in 2007. (Unkašević \& Tošić, 2013). This coincides with the occurrence of 5 and 6 consecutive days with the VSHS category during July and August in 2012. Besides, during 2007, 2015 and 2017, a maximum of 8 consecutive days with the VSHS category was recorded, which indicates more extended periods of extremely hot biothermal discomfort in the last ten years of the observed period. As a result, the number of events that represent a duration of very strong heat stress of minimum 5 consecutive days of VSHS (called very strong heat stress event) increased in the observed period starting in 2007, with a total of 7 events in 5 years. Moreover, very strong heat stress (VSHS) starts to appear in September, starting in 2008. In that regard, September 2015 had five days with UTCl above $38^{\circ} \mathrm{C}$, with a recorded maximum of $40.6^{\circ} \mathrm{C}$ which was certainly an unusually extreme month for Serbia making September 2015 stand out as a month with extreme heat stress. The increasing of heat stress agrees with the finding that heatwaves began to appear in September in the last decade (Tomczyk, 2016). According to the interpretation of $\mathrm{Di}$ Napoli et al. (2018) about two thermal climates in Europe where one of them is associated with heat stress condition and is predominant in the southern part of Europe (including Balkans), moderate and strong heat stress happen at 13 (14.00 local time) reflect the general relationship between heat load and insolation. This is also in agreement with the statement of Di Napoli et al. (2019) about UTCI reference value from 1979-2016, where the UTCl at 12 o'clock (UTC) was about $0.5^{\circ} \mathrm{C}$ colder in the 1980-1999 period while it was $0.5^{\circ} \mathrm{C}$ warmer in the $2000-2009$ period and $1^{\circ} \mathrm{C}$ warmer in the $2010-2016$ period. Similar findings were reported by Kuchcik (2017) for Poland.

Diurnal UTCI change (dUTCI) shows more detailed daily fluctuations of the UTCI index. Namely, there is an increase of days with positive dUTCl and a decrease of days with negative dUTCl during summer, while there is a decline in negative dUTCI in winter. It was particularly pronounced during the spring (March, April) and autumn (November) in the last ten years, where the dominant number of days with cold stress is replaced by the dominant number of days with warm stress. This is in agreement with the statement of di Napoli et al. (2018a) where heat stress follows a diurnal pattern with UTCI values at 6.00 or 18.00 generally lower than UTCI values at 12.00 or 15.00 . The difference in the UTCI hourly values is considered of importance due to human reaction on a daily thermal fluctuation. The negative daily change of the UTCI is a consequence of the decrease in daily temperature during the day due to a sudden change in weather caused by a rapid drop in atmospheric pressure resulting in strong wind gusts and a rapid drop in temperature during the day, mainly related due to atmospheric circulation. On the other hand, 
the positive daily change of the UTCI is related to the typical daily flow of meteorological parameters.

Based on the assessment of UTCl and the interpretation of human bioclimatic conditions in Vranje health resort region, during the period 2000-2017, the most extreme years can be distinguished by several characteristics:

- Extreme years in the summer season (2007, 2015)

- Extreme years for both summer and winter seasons (2000, 2003, 2012, 2017)

- Extreme years in the winter season (2001, 2002, 2004)

- Unusually extreme month (September 2015)

- Extreme days with increasing heat stress excluding summer (dUTCl >0) (November 2008-2012, 2017)

However, in recent research, the UTCI has been increasingly helping as a determinant of extreme weather condition (Theoharatos et al., 2010; Urban \& Kyselý, 2014; Di Napoli et al., 2018, 2019; Pecelj et al., 2020). Furthermore, complete hourly weather data are missing in order to be able to analyse UTCI values in more detail which might be applied for health purposes considering the vicinity of health spa resort Vranjska Banja. Otherwise, bioclimatic analysis of health spa resorts could be more complete with an adequate assessment of Solar ultraviolet (UV) radiation as a significant health hazard in the warm part of the year suggested by Malinović et al. (2020) and air quality assessments based on lichens as indicators proposed by Djekić et al. (2020) or PM2.5 concentrations suggested by Stanojević et al. (2019).

Nevertheless, the research results of this study highlight the importance of the UTCI as a bioclimatic index that covers the thermal bioclimatic variability of Vranje (South Serbia) mainly if the variability is related to the effects on human health. Thermal bioclimatic variability plays an essential role in the interpretation of health spa resorts, due to outdoor recreation, as it is assessed in the context of physiological processes in humans. This study features a human bioclimatic method in analysing biothermal conditions with particular emphasis on extremes, so as to understand better their impact on rehabilitation in health spa resorts, human health and well-being.

Editors' note:

Unless otherwise stated, the sources of tables and figures are the authors', on the basis of their own research.

\section{References}

Anagnostopoulou, C., Tolika, K., Lazoglou, G., Machairas, P. (2017). The Exceptionally cold January of 2017 over the Balkan Peninsula: A climatological and synoptic analysis. Atmosphere, 8(12), 252. https://doi.org/10.3390/atmos8120252

Basarin, B., Lukić, T., Matzarakis, A. (2016). Quantification and assessment of heat and cold waves in Novi Sad, Northern Serbia. International Journal of Biometeorology, 60, 139-150. https://doi.org/10.1007/s00484-015-1012-z

Basarin, B., Lukić, T., Mesaroš, M., Pavić, D., Djordjević, J., Matzarakis, A. (2018). Spatial and temporal analysis of extreme bioclimate conditions in Vojvodina, Northern Serbia. International Journal of Climatology, 38, 142-157. https://doi.org/10.1002/joc.5166

BioKlima, 1994. BioKlima 2.6 (version 2.6) - Universal tool for bioclimatic and thermophysiological studies. https://www.igipz.pan.pl/Bioklima-zgik.html

Bleta, A., Nastos, P., Matzarakis, A. (2014). Assessment of bioclimatic conditions on Crete Island, Greece. Regional Environmental Changes, 14, 1967-1981. https://doi.org/10.1007/s10113-013-0530-7 
Błażejczyk, K., Błażejczyk, A. (2014). Assessment of bioclimatic variability on regional and local scales in central Europe using UTCI. Scientific Annals of "Alexandru loan Cuza" University of IASI, 60(1), S. II C., Geography Series, AL.I. Cuza University Press, 67-82.

Błażejczyk, K., Bröde, P., Fiala, D., Havenith, G., Holmér, I., Jendritzky, G., Kampmann, B., Kunert, A. (2010b). Principles of the new universal thermal climate index (UTCI) and its application to bioclimatic research in European scale. Miscellanea Geographica, 14, 91-102. https://doi.org/10.2478/mgrsd-2010-0009

Błażejczyk, K., Bröde, P., Fiala, D., Havenith, G., Jendritzky, G., Kampmann, B. (2010a). UTCl - New index for assessment of heat stress in man. Przeglad Geograficzny, 82, 49-72. https://doi.org/10.7163/PrzG.2010.1.2

Błażejczyk, K., Epstein, Y., Jendritzky, G., Staiger, H., Tinz, B. (2012). Comparison of UTCl to selected thermal indices. International Journal of Biometeorology, 56(3), 515-535. https://doi.org/10.1007/s00484-011-0453-2

Błażejczyk, K., Jendritzky, G., Brode, P., Fiala, D., Havenith, G., Epstein, Y., Psikuta, A., Kampmann, B. (2013). An introduction to the Universal Thermal Climate Index (UTCI). Geographia Polonica, 86(1), 5-10. http://doi.org/10.7163/GPol.2013.1

Błażejczyk, K., Kunert, A. (2011). Bioclimatic principles of recreation and tourism in Poland. 2nd edition. Monografie, 13. Warsaw: IGiPZ PAN.

Błażejczyk, K., Twardosz, R. (2010). Long-term changes of bioclimatic conditions in Cracow (Poland). In R. Przybylak, R. Majorowicz, J. Brázdil, M. Kejna (Eds.), The Polish Climate in the European Context: An Historical Overview. pp. 235-246. Springer, Science + Business Media B.V. https://doi.org/10.1007/978-90-481-3167-9_10

Bröde, P., Krüger, E.L., Rossi, F.A., Fiala, D. (2012). Predicting urban outdoor thermal comfort by the Universal Thermal Climate Index UTCl-a case study in Southern Brazil. International Journal of Biometeorology, 56(3), 471-480. https://doi.org/10.1007/s00484-011-0452-3

Burkart, K., Meier, F., Schneider, A., Breitner, S., Canário, P., Alcoforado, M.J. Scherer, D., Endlicher, W. (2016). Modification of heat-related mortality in an elderly urban population by vegetation (urban green) and proximity to water (urban blue): Evidence from Lisbon, Portugal. Environmental Health Perspectives, 124, 927-934. https://doi.org/10.1289/ehp.1409529

Cheung, C.S.C., Hart, M.A. (2012). Climate change and thermal comfort in Hong Kong. International Journal of Biometeorology, 58(2), 137-148. https://doi.org/10.1007/s00484-012-0608-9

Coutts, A.M., White, E.C., Tapper, N.J., Beringer, J., Livesley, S.J. (2016). Temperature and human thermal comfort effects of street trees across three contrasting street canyon environments. Theoretical and Applied Climatology, 124(1-2), 55-68. https://doi.org/10.1007/s00704-015-1409-y

Croitorua, A.E., Piticarb, A. (2013). Changes in daily extreme temperatures in the extra-Carpathians regions of Romania. International Journal of Climatology, 33, 1987-2001. https://doi.org/10.1002/joc.3567

Denda, S.LJ, Micić, J.M. Milanović Pešić, A.Z., Brankov, J.J., Bjeljac, Ž.N. (2019). Utilization of geothermal springs as a renewable energy source: Vranjska Banja case study. Thermal Science, 23(6B), 4083-4093. https://doi.org/10.2298/TSCl190816391D

Di Napoli, C., Pappenberger, F., Cloke, H.L. (2018). Assessing heat-related health risk in Europe via the Universal Thermal Climate Index (UTCI). International Journal Biometeorology, 62(7), 1155-1165. https://doi.org/10.1007/s00484-018-1518-2

Di Napoli, C., Pappenberger, F., Cloke, H.L. (2019). Verification of heat stress thresholds for a healthbased heat-wave definition. Journal of Applied Meteorology and Climatology, 58(6), 1177-1194. https://doi.org/10.1175/JAMC-D-18-0246.1

Djekić, T., Ristić, S., Stamenković, S., Šajn, R., Engelman, M. (2020). Lichens as indicators of air quality in balneological center Prolom Banja (Southern Serbia). Journal of the Geographical Institute "Jovan Cvijic' SASA, 70(2), 101-113. https://doi.org/10.2298/IJGI2002101D 
Drljača, V., Tošić, I., Unkašević, M. (2009). An analysis of heat waves in Belgrade and Niš using the climate index. Journal of Geographical Institute Jovan Cvijić SASA, 59(1), 49-62. https://doi.org/10.2298/IJGI0959049D

Farajzadeh, H., Saligheh, M., Alijani, B., Matzarakis, A. (2015). Comparison of selected thermal indices in the northwest of Iran. Natural Environment Change, 1(1), 1-20.

Hartz, D.A., Brazel, A.J., Golden, J.S. (2013). A comparative climate analysis of heat-related emergency 911 dispatches: Chicago, Illinois and Phoenix, Arizona USA 2003 to 2006. International Journal of Biometeorology, 57(5), 669-678. https://doi.org/10.1007/s00484-012-0593-z

Havenith, G., Fiala, D., Błazejczyk, K., Richards, M., Bröde, P., Holmér, I., Rintamaki, H., Benshabat, Y., Jendritzky, G. (2012). The UTCI clothing model. International Journal of Biometeorology, 56(3), 461-470. https://doi.org/10.1007/s00484-011-0451-4

Honjo, T., Seo, Y., Yamasaki, Y., Tsunematsu, N., Yokoyama, H., Yamato, H., Mikami, T. (2018). Thermal comfort along the marathon course of the 2020 Tokyo Olympics. International Journal of Biometeorology, 62(8), 1407-1419. https://doi.org/10.1007/s00484-018-1539-x

Hundecha, Y, Bardossy, A. (2005). Trends in daily precipitation and temperature extremes across Western Germany in the second half of the 20th century. International Journal of Climatology, 25, 1189-1202. https://doi.org/10.1002/joc.1182]

IPCC. 2007. In Climate Change: The Physical Science Basis, Contribution of Working Group I to the Fourth Assessment Report of the Intergovernmental Panel on Climate Change. Solomon S., Qin D., Manning M., Chen Z., Marquis M., Averyt K.B., Tignor M., Miller H.L. (Eds.), Cambridge, United Kingdom and New York, NY, USA: Cambridge University Press.

Jendritzky, G., de Dear, R., Havenith, G. (2012). UTCI - why another thermal index? International Journal of Biometeorology, 56(3), 421-428. https://doi.org/10.1007/s00484-011-0513-7

Kolendowicz, L., Półrolniczak, M., Szyga-Pluta, K., Bednorz, E. (2018). Human-biometeorological conditions in the southern Baltic coast based on the universal thermal climate index (UTCI). Theoretical and Applied Climatology, 134, 363-379. https://doi.org/10.1007/s00704-017-2279-2

Kostopoulou, E., Jones, P. (2005). Assessment of climate extremes in Eastern Mediterranean. Meteorological and Atmospherical Physics, 89, 69-85. https://doi.org/10.1007/s00703-005-0122-2

Kottek, M., Greiser, J., Beck, C., Rudolf, B., Rubel, F. (2006). World Map of the Koppen-Geiger climate classification updated. Meteorologische Zeitschrif, 15(3), 259-263. https://doi.org/10.1127/0941-90 2948/2006/0130

Kuchcik, M. (2017). Zmiany warunków termicznych w Polsce na przełomie XX i XXI wieku i ich wpływ na umieralność. Prace Geograficzne, 263, Warsaw: IGiPZ PAN.

Malinović-Milićević, S., Mijatović, Z., Arsenić, I., Podrašćanin, Z., Firanj Sremac, A., Radovanović, M., Drešković, N. (2020). The importance of ground-based and satellite observations for monitoring and estimation of UV radiation in Novi Sad (Serbia). Journal of the Geographical Institute "Jovan Cvijić" SASA, 70(1), 57-70. https://doi.org/10.2298/IJGI2001057M

Matzarakis, A., Muthers, S., Rutz, F. (2014). Application and comparison of UTCl and PET in temperate climate conditions. Finisterra, 49, 21-31. https://doi.org/10.18055/Finis6453

Mąkosza, A., Nidzgorska-Lencewicz, J. (2017). Selected thermal and biothermal aspects of cities in Poland. Polish Journal of Natural Science, 32(4), 771-782.

McGregor, G., Vanos, J. (2018). Heat: A primer for public health researchers. Public Health, 161, 138-146. https://doi.org/10.1016/j.puhe.2017.11.005

Meteorological Yearbook, 2000-2018. Republic Hydrometeorological Service of Serbia. http://www.hidmet.gov.rs/latin/meteorologija/klimatologija_godisnjaci.php

Milewski, P. (2013). Application of the UTCI to the local bioclimate of Poland's Ziemia Kłodzka Region. Geographia Polonica, 86(1), 47-54. https://doi.org/10.7163/GPol.2013.6 
Milivojevic, M., Krunic, O., Martinovic, M. (2005). Serbian spas as a base for tourism development. In Proceedings World Geothermal Congress, Antalya, Turkey, 24-29 April 2005. https://www.geothermal-energy.org/pdf/IGAstandard/WGC/2005/2110.pdf

Milovanović, B., Radovanović, M., Stanojević, G., Pecelj, M., Nikolić, J. (2017a). Klima Srbije. In M. Radovanović (Ed.), Geografija Srbije (pp. 94-105). Belgrade, Serbia: Geographical Institute Jovan Cvijić SASA.

Milovanović, B., Ducić, V., Radovanović, M., Milivojević, M. (2017b). Climate regionalisation of Serbia according to Köppen climate classification. Journal of the Geographical Institute "Jovan Cvijić" SASA, 67(2), 103-114. https://doi.org/10.2298/IJGl1702103M

Milovanović, B., Schuster, P., Radovanović, M., Ristić Vakanjac, V., Schneider, C., Milivojević, M. (2018). Spatial-Temporal variabilitz of air temperatures in Serbia in the period 1961-2010. Journal of Geographical Institute Jovan Cvijić SASA, 68(2), 157-175. https://doi.org/10.2298/IJGI1802157M

NASA. 2000. N42E021.SRTMGL1; N42E022.SRTMGL1 (Shuttle Radar Topography Mission - SRTM). http://earthexplorer.usgs.gov/(November, 2019)

Nassiri, P., Monazzam, M.R., Golbabaei, F., Farhang Dehghan, S., Rafieepour, A., Mortezapour, A.R., Asghari, M. (2017). Application of Universal Thermal Climate Index (UTCl) for assessment of occupational heat stress in open-pit mines. Industrial Health, 55(5), 437-443. https://doi.org/10.2486/indhealth.2017-0018

Nastos, P., Matzarakis, A. (2012). The effect of air temperature and human thermal indices on mortality in Athens, Greece. Theoretical and Applied Climatology, 108, 591-599. https://doi.org/10.1007/s00704-011-0555-0

Nemeth, A. (2011). Changing thermal bioclimate in some Hungarian cities. Acta Climatologica Chorologica, 44-45, 93-101.

Pecelj, M., Đordđević, A., Pecelj, M.R., Pecelj-Purković, J., Filipović, D., Šećerov, V. (2017). Biothermal conditions on Mt. Zlatibor based on thermophysiological indices. Archive of Biological Sciences, 69(3), 455-461. https://doi.org/10.2298/ABS151223120P

Pecelj, M.M., Lukić, M.Z., Filipović, D.J., Protić, B.M., Bogdanović, U. (2020). Analysis of the Universal Thermal Climate Index during heat waves in Serbia. Natural Hazards and Earth System Science, 20, 2021-2036. https://doi.org/10.5194/nhess-20-2021-2020

Pecelj, M., Lukić, M., Vučičević, A., De Una-Alvarez, E., Esteves da Silva, CGJ., Freinkin, I., Ciganović, S., Bogdanović, U. (2018). Geoecological evaluation of local surroundings for the purposes of recreational tourism. Journal of Geographic Institute Jovan Cvijic SASA, 68(2), 215-231. https://doi.org/10.2298/IJGI1802215P

Pecelj, M.M., Trbić, G., Pecelj, M.R. (2013). Biothermal condition based on the Bioclimatic Index Heat Load. In Proceeding of the 6th International Conference on Climate Change, Global Warming and Biological Problems, Recent Advances in Environmental Science (pp. 250-254). Frederick University, Cyprus, Limassol.

Potchter, O., Cohen, P., Lin, TP., Matzarakis, A. (2018). Outdoor human thermal perception in various climates: A comprehensive review of approaches, methods and quantification. Science of the Total Environment, 631-632, 390-406. https://doi.org/10.1016/j.scitotenv.2018.02.276

Radinović, D., Ćurić, M. (2011). Criteria for heat and cold wave duration indexes. Theoretical and Applied Climatology, 107(3-4), 505-510. https://doi.org/10.1007/s00704-011-0495-8

Roshan, G., Yousefi, R., Błażejczyk, K. (2018). Assessment of the climatic potential for tourism in Iran trough biometeorology clustering. International Journal of Biometeorology, 62(4), 525-542. https://doi.org/10.1007/s00484-017-1462-6

Stamenković, S. (1995). Vranje, geneza i naseobinska evolucija. Beograd: Geografski fakultet Univerziteta u Beogradu.

Stanojević, G.B., Miljanović, D.N., Doljak, D. Lj., Ćurčić, N.B., Radovanović, M.M., Malinović-Milićević, S.B., Hauriak, O. (2019). Spatio-temporal variability of annual PM2.5 concentrations and 
population exposure assessment in Serbia for the period 2001-2016. Journal of the Geographical Institute "Jovan Cvijić" SASA, 69(3), 197-211. https://doi.org/10.2298/IJGI1903197S

Stevanović, V. (2019). Elements of bioclimatological characteristics of Vranjska spa. The University Thought-Public in Natural Sciences, 9(1), 45-48. https://doi.org/10.5937/univtho9-22125

Theoharatos, G., Pantavou, K., Mavrakis, A., Spanou, A., Katavoutas, G., Efstathiou, P., Mpekas, P., Asimakopoulos, D. (2010). Heat waves observed in 2007 in Athens, Greece: Synoptic conditions, bioclimatological assessment, air quality levels and health effects. Environmental Research, 110, 152-161. https://doi.org/10.1016/j.envres.2009.12.002

Tolika, K., Maheras, P., Pytharoulis, I., Anagnostopoulou, C. (2014). The anomalous low and high temperatures of 2012 over Greece - An explanation from a meteorological and climatological perspective. Natural Hazards and Earth System Sciences, 14(3), 501-507. https://doi.org/10.5194/nhess-14-501-2014

Tomczyk, A.M. (2016). Impact of atmospheric circulation on the occurrence of heat waves in southeastern Europe. Idojárás, 120(4), 395-414.

Tomczyk, A.M., Owczarek, M. (2019). Occurrence of strong and very strong heat stress in Poland and its circulation conditions. Theoretical and Applied Climatology, 139, 893-905. https://doi.org/10.1007/s00704-019-02998-3

Unkašević, M., Tošić, I. (2011). The maximum temperatures and heat waves in Serbia during the summer of 2007. Climate Change, 108(1-2), 207-223. https://doi.org/10.1007/s10584-010-0006-4

Unkašević, M., Tošić, I. (2015). Seasonal analysis of cold and heat waves in Serbia during the period 1949-2012. Theoretical and Applied Climatology, 120(1-2), 29-40. https://doi.org/10.1007/s00704-014-1154-7

Urban, A., Kyselý, J. (2014). Comparison of UTCI with other thermal indices in the assessment of heat and cold effects on cardiovascular mortality in the Czech Republic. International Journal of Environmental Research Public Health, 11(1), 952-967. https://doi.org/10.3390/ijerph110100952

Vissine, W., Houssou, S.C., Błażejczyk, K. (2013). Application de l'indice universel de charge thermique dans le contexte Africain: Exemple de Cotonou (Repiblique du Benin). In Conference paper: XXVlème colloque de l'Association Internationale de Climatologie (pp. 105-109). 